NBER WORKING PAPER SERIES

\title{
INFLATION TARGETING IN TRANSITION COUNTRIES: EXPERIENCE AND PROSPECTS
}

\author{
Jiri Jonas \\ Frederic S. Mishkin \\ Working Paper 9667 \\ http://www.nber.org/papers/w9667
NATIONAL BUREAU OF ECONOMIC RESEARCH 1050 Massachusetts Avenue Cambridge, MA 02138
April 2003

The views expressed in this paper are exclusively those of the authors and not those of the International Monetary Fund, Columbia University, or the National Bureau of Economic Research. We thank the participants in the Macro Lunch at Columbia University and the NBER Inflation Targeting Conference for their helpful comments.

(C2003 by Jiri Jonas and Frederic S. Mishkin. All rights reserved. Short sections of text not to exceed two paragraphs, may be quoted without explicit permission provided that full credit including Cnotice, is given to the source. 
Inflation Targeting in Transition Countries: Experience and Prospects

Jiri Jonas and Frederic S. Mishkin

NBER Working Paper No. 9667

April 2003

JEL No. E5

\section{ABSTRACT}

This paper examines the inflation targeting experience in three transition countries: the Czech Republic, Poland and Hungary. While the examined countries have missed inflation targets often by a large margin, they nevertheless progressed well with disinflation. A key lesson from the experience of the inflation targeting transition countries is that economic performance will improve and support for the central bank will be higher if the central banks emphasize avoiding undershoots of the inflation target as much as avoiding overshoots. Also economic performance will be enhanced if inflation targeting central banks in transition countries do not engage in active manipulation of the exchange rate. The relationship between the central bank and the government in these countries has been quite difficult, but this can be alleviated by having a direct government involvement in the setting of the inflation target and with a more active role of the central bank in communicating with both the government and the public. In addition having technocrats appointed as the head of the central bank rather than politicians may help in depersonalizing the conduct of monetary policy and increase support for the independence of the central bank. The paper also addresses the future perspective of monetary policy in the transition economies and concludes that even after the EU accession, inflation targeting can remain the main pillar of monetary strategy in the three examined accession countries during the time before they will join the EMU.

Jiri Jonas

International Monetary Fund $70019^{\text {th }}$ Street, NW

Washington, DC 20431

jjones@imf.org
Frederic S. Mishkin

Graduate School of Business

Uris Hall 619

Columbia University

New York, NY 10027

and NBER

fsm3@columbia.edu 


\section{Introduction}

In the second half of the 1990s, several transition countries have abandoned fixed exchange rate regimes, and instead introduced inflation targeting as framework for the conduct of monetary policy. In this paper, we will analyses the experience of three countries that moved to an inflation targeting regime: the Czech Republic, Hungary and Poland.

It is worth studying inflation targeting in these transition countries for two reasons. First, the transition countries are becoming an important part of Europe and designing the right monetary policy regime for their transition to successful European economies is valuable in its own right. Second, these countries have three unique features that make the study of inflation targeting in these countries particularly interesting: 1) they are new democracies that are in the process of developing new governmental institutions; 2) their economies are undergoing radical restructuring as part of the transition from communism to capitalism; and 3) they are very likely to enter the European Union (EU) and Economic and Monetary Union (EMU) in the near future. These three unique features are emphasized in our discussion of their inflation targeting regimes.

In the next section of the paper we discuss the reasons why these countries moved to a more flexible exchange rate regime and for the introduction of inflation targeting. In the third section, we examine in more detail the introduction of inflation targeting in the three countries, and in the fourth section, we evaluate the preliminary experience with inflation targeting. In the fifth section, we discuss a number of specific issues for inflation targeting in transition economies: what inflation measure to target, whether to target a point or a range, what should be the time horizon for the inflation target, who should set the inflation target, what should be the response to faster than targeted disinflation, how monetary policy should respond to deviations of inflation from the target, how much should the floor of the inflation target be emphasized relative to the ceiling, and what role should the exchange rate play in an inflation targeting regime. In section 6 , we discuss the future prospects of inflation targeting in transition economies in connection with the planned entry into EMU, focusing on inflation targeting within the fluctuation band of ERM2 regime and on the potential conflict between the inflation target and the exchange rate target. The final section contains concluding remarks.

\section{From peg to float}

In economic history books, the 1990 s will be probably remembered as a decade when fixed exchange rate regimes lost much of their attraction as nominal anchors for the conduct of monetary policy. As a result of devastating financial crises, many emerging market countries were forced to abandon fixed exchange rate regimes, and replace them with more flexible exchange rate arrangements. Some countries - though a significant minority even opted to introduce more flexible exchange rate regime in an orderly way, without being forced to exit the peg as a result of financial crisis or market pressure on their currency. 
This trend from a more fixed to more flexible exchange rate regimes was also observed in transition economies of Central and Eastern Europe. In the early years of transition, in the aftermath of price liberalization and exchange rate devaluation, many transition economies have used the exchange rate peg as a nominal anchor to achieve a rapid stabilization of price level. However, as with other emerging market economies, transition economies too have suffered the standard problem of exchange rate-based stabilization programs: while inflation did decline significantly, it did not decline enough to prevent a large real appreciation that ultimately created a balance of payment problems and forced the abandonment of the fixed exchange rate. While some countries opted for a hard version of a fixed exchange rate - a currency board arrangement, others introduced managed float: first the Czech Republic in 1997, then the Slovak Republic and Poland in 1998. Hungary did not move to a full floating currency regime, but in May 2001, it introduced an exchange rate band, allowing the currency to move up and down within this band by 15 percent.

When abandoning the exchange rate pegs, the authorities of these countries had to decide what nominal anchor to use instead of the fixed exchange rate. While the Slovak Republic did not accompany the move to a floating exchange rate by an explicit introduction of new monetary policy framework, the other three countries opted for inflation targeting. Why did the authorities in these countries opted for inflation targeting, and why did they reject other alternative policy frameworks? We can see why by examining the problems of other monetary policy regimes.

One alternative would be to use monetary aggregates as an intermediate target and nominal anchor. However, targeting monetary aggregates does not have much attraction in transition economies. ${ }^{1}$ The traditional problem of instability of money demand, and therefore the unstable relationship between the growth of money supply and inflation, could be a particularly serious obstacle to targeting monetary aggregates in transition economies. Economic transition is characterized by a sequence of price shocks, including corrections in administered prices and tax reforms, that make the relationship between money supply and price level very difficult to predict. The instability of money demand and money-price relationship is further exacerbated by far-reaching changes in financial sector, including deep institutional changes, emergence of new types of financial assets and players etc. Therefore, relying solely on targeting money supply growth could be a quite ineffective approach to conducting monetary policy.

Transition economies could have also applied a discretionary, "just-do-it" approach to monetary policy as the Federal Reserve in the United States is doing, in which there is no

\footnotetext{
${ }^{1}$ Indeed, it is not at all clear that monetary targeting is a viable strategy, even in industrialized countries, because the relationship between monetary aggregates and goal variables such as inflation and nominal spending is typically quite weak. For example, see Estrella and Mishkin (1997).
} 
explicit nominal anchor. ${ }^{2}$ Given the difficulty of establishing a more stable relationship between some intermediate target and price level, some may think that a less formal approach to monetary policy would be advisable. However, while this approach may work in countries whose central bank has well-established anti-inflationary credibility, and where inflation is low, it was doubtful that it would work well in transition economies. Particularly in the Czech Republic where inflation was relatively high and rising after the fixed exchange rate regime was abandoned, the just-do-it approach to monetary policy was not seen as being potentially effective in bringing inflation expectations and actual inflation down. Without anti-inflation credibility, the just-do-it approach would not sufficiently anchor inflation expectations and persuade economic agents that monetary policy would be actually conducted to control inflation.

A third option would be to replace a fixed exchange rate regime with a harder variant of exchange rate peg, that is, by introducing a currency board, or even unilaterally euroizing. This option has the advantage that it provides a nominal anchor that helps keep inflation under control by tying the prices of domestically-produced tradable goods to those in the anchor country, and making inflation expectations converge to those prevailing in the anchor country. In addition, it provides an automatic adjustment mechanism that helps mitigate the time-inconsistency problem of monetary policy. Hard pegs also have the advantage of simplicity and clarity, which make them easily understood by the public. However, the hard peg option has the disadvantage that it leaves little scope for the country to conduct its own monetary policy in order to react to domestic or foreign shocks.

For transition countries that wanted to retain some control over domestic monetary policy and so opted to keep a flexible exchange rate, the problems with monetary targeting and the just-do-it approach led them to adopt a fourth option, inflation targeting. Inflation targeting has several advantages over a hard peg, monetary targeting or the just-do-it approach. In contrast to a hard peg, inflation targeting enables monetary policy to focus on domestic considerations and to respond to shocks of both domestic and foreign origin. Inflation targeting also has the advantage that stability in the relationship between money and inflation is not critical to its success because it does not depend on such a relationship. Inflation targeting, like a hard peg, also has the key advantage that it is easily understood by the public and thus highly transparent. In contrast, monetary targets, although visible, are less likely to be well understood by the public, especially as the relationship between monetary aggregates and inflation becomes less stable and reliable. Because an explicit numerical target for inflation increases the accountability of the central bank relative to a

${ }^{2}$ For a description of the just-do-it approach in the United States, see Bernanke et al. (1999). Some transition economies are pursuing a managed float (Romania, Slovak Republic, Slovenia) or free float (Albania) without a formal inflation targeting framework in place, though Albania is now introducing full-fledged inflation targeting. It is interesting to compare the development of inflation in these countries that have similarly flexible exchange rate regimes but no formal inflation targeting regime in place (see section IV.c.). 
discretionary regime, inflation targeting also has the potential to reduce the likelihood that the central bank will fall into the time-inconsistency trap. Moreover, since the source of time-inconsistency is often found in (covert or open) political pressures on the central bank to engage in expansionary monetary policy, inflation targeting has the advantage of focusing the political debate on what a central bank can do on a sustainable basis--i.e., control inflation--rather on than what it cannot do through monetary policy--e.g., raise output growth, lower unemployment, or increase external competitiveness.

How well were the transition economies prepared for the introduction of inflation targeting? In the literature, a relatively long list of requirements has been identified that countries should meet if inflation targeting regime is to operate successfully. ${ }^{3}$ These requirements include: (1) a strong fiscal position; (2) a well understood transmission mechanisms between monetary policy instruments and inflation; (3) a well-developed financial system; (4) central bank independence and a clear mandate for price stability; (5) a reasonably well-developed ability to forecast inflation; (6) absence of other nominal anchors than inflation; and (7) transparent and accountable monetary policy.

It is not possible to say whether a country meets these requirements or not: it is more a question of degree to which these preconditions are met. On the whole, it could be argued that the three transition countries that adopted inflation targeting, the Czech Republic, Hungary and Poland, met these requirements to a sufficient degree to make inflation targeting feasible and useful. ${ }^{4}$

All three countries have an independent central bank with a clear mandate to pursue price stability. In some cases, this independence and price stability mandate has been strengthened just before the introduction of inflation targeting. There has been also significant progress in making monetary policy decisions more transparent and central banks more accountable, though this is still to some extent a work in progress in some countries. Financial markets in the three analyzed economies are relatively well developed, allowing for a reasonably effective transmission mechanism between monetary policy instruments and inflation.

With respect to fiscal position, partly as a result of explicit recognition of hidden transformation-related costs, fiscal deficits have widened significantly, particularly in the Czech Republic and Hungary (see table 1). However, these deficits have not yet posed a direct problem to inflation targeting in the sense of fiscal dominance of monetary policy,

\footnotetext{
${ }^{3}$ See Debelle (1997) and Schaechter et. al. (2000).

${ }^{4}$ For discussion of whether Hungary is ready for inflation targeting, see Siklos and Ábel (2001).
} 
because they have been financed by non-monetary means at relatively favorable terms. ${ }^{5}$ The main reason why large fiscal deficits in accession countries do not trigger adverse market reaction is that they are widely considered to be temporary. Partly, this reflects the recognition of implicit public sector liabilities from the past. Moreover, as a result of EU/EMU accession, these countries will adopt an institutional framework (Stability and Growth Pact, SGP) that will require them to pursue disciplined fiscal policies. Still, before the constraint of the SGP begins to operate, large fiscal deficits can complicate monetary policy conduct in indirect ways as we will see in our later discussion of these three countries experience with inflation targeting.

Table 1. Inflation-targeting countries: general government balance (in \% of GDP) $1 /$

\begin{tabular}{|l|l|l|l|l|}
\hline & 1998 & 1999 & 2000 & 2001 \\
\hline Czech Republic & -2.4 & -2.0 & -4.2 & -5.2 \\
\hline Hungary & -4.8 & -3.4 & -3.3 & -4.7 \\
\hline Poland & -3.2 & -3.7 & -3.2 & -6.0 \\
\hline
\end{tabular}

1/ Excludes privatization revenues

Source: European Bank for Reconstruction and Development (2002)

As for the absence of multiple nominal anchors, this condition is clearly met in the Czech Republic and Poland. These countries have in place a regime of managed float, and inflation is the only nominal anchor in the economy. In Hungary, the situation is more complicated, because of the presence of the exchange rate band. Theoretically, this could be incompatible with the requirement of the single nominal anchor if the band is too narrow. We should note that the existence of the exchange rate fluctuation band is is not only an issue of concern to Hungary today, but it will be of concern to all transition countries that would join the ERM2 system, when they will have to put in place the same fluctuation band. We will discuss the issue of fluctuation band and inflation targeting in the section on monetary policy within the ERM2 system.

Perhaps the most serious objection raised against the adoption of inflation targeting in transition economies is the limited ability to forecast accurately inflation. This is partly the result of the relatively frequent occurrence of shocks to which transition economies are exposed, including price deregulation and catching up with the more advanced economies, and also the result of relatively large degree of openness of these economies. Actual inflation is relatively unstable relative to the long-term inflation trend (Orlowski, 2000). Under such circumstances, there are natural limits to central banks' ability to forecast inflation that cannot be quickly and substantially improved by more sophisticated forecasting models.

\footnotetext{
${ }^{5}$ Note that one can argue that a strong fiscal position is a requirement for successful conduct of monetary policy under any policy framework, not just inflation targeting. See Eichengreen (1999) and Mishkin and Savastano (1999).
} 
However, inflation-targeting central banks are nevertheless making progress in improving their inflation-forecasting capacity. One approach is to use alternative and less formal methods of gauging future inflation. For example, in 1999, the Czech National Bank has introduced a survey of inflation forecasts by market participants to measure inflation expectations.

\section{Introduction of inflation targeting in individual countries}

We will now turn in more detail to the introduction of inflation targeting in individual countries. We will briefly examine economic developments preceding the introduction of inflation targeting, and the main operational characteristics of the inflation targeting regimes in the three countries.

\section{3.a. Czech Republic}

The Czech Republic was the first transition economy that introduced an inflation targeting regime, after it has abandoned fixed exchange rate regime following currency turbulence in May 1997.

A fixed exchange rate regime played an important role in the macroeconomic stabilization package introduced in 1991. Several months after liberalization of prices and devaluation of currency in 1991, the rate of inflation has come down quickly, though not quite to levels prevailing in advanced economies. Inflation remained stuck at around 10 percent, and wages and other nominal variables soon adjusted to this level. Higher domestic inflation and the fixed nominal exchange rate produced a real appreciation which was not fully validated by higher productivity growth, and after some time, erosion of competitiveness became a concern. The economy began to overheat, political constraints prevented a sufficiently vigorous and flexible use of fiscal policy to mitigate imbalances in nonpublic sector, and tightening of monetary policy alone could not cope with these rapidly growing imbalances. The mix of tighter monetary and continued loose fiscal policy may have only made things worse: it contributed to higher interest rates which attracted more shortterm foreign capital, fueling further the growth of liquidity, keeping inflation high and widening the current account deficit.

Ultimately, as the external deficit continued to widen despite the visible deceleration of economic growth later in 1996, the situation became unsustainable. It became increasingly obvious that policy adjustment that was feasible under the existing political constraints would fall short of what was needed to reverse the unsustainable deterioration of current account position. Uncertainties in financial markets, triggered initially by speculative attacks on the Thai baht, only accelerated the flight of foreign investors from koruna assets which forced 
the authorities to stop defending a fixed exchange rate. On May 26, 1997, the government and the Czech National Bank (CNB) decided to allow the koruna to float freely. ${ }^{6}$

Like many other emerging market countries, the Czech Republic did not exit the peg at a time of strong external position, but only when it was forced to do so by market pressure. However, unlike other central banks that were ultimately forced to abandon the defense of a fixed parity, the CNB did not wait too long after the pressure on the koruna intensified. Even though it first tried to fend off the pressure by raising interest rates, it did not waste a large amount of foreign reserves in foreign exchange market intervention. In the week before the decision to float, CNB's foreign reserves declined by about $\$ 2.5$ billion, to $\$ 10$ billion. Given the unsatisfactory experience with interventions as a tool to prevent the exit from a pegged exchange rate regime, this was a correct decision.

Possible inflationary effects of currency depreciation after the exit from the peg, together with the absence of alternative nominal anchor to guide inflation expectations, created a risk that inflation would increase significantly in the coming months. Therefore, the CNB began to work on a new monetary policy framework, and in the meantime, it tried to guide inflation expectations by its public pronouncements. After the koruna was allowed to float, the CNB issued a public statement that it expected the average koruna exchange rate will stabilize within months at roughly CZK 17 to 19.50 per 1 DEM (Czech National Bank, 1997). Furthermore, the CNB made it clear that in the future, monetary policy would be unambiguously focused on domestic price level stability and reduction of potential inflationary effects of the koruna's exchange rate movements (Czech National Bank, 1997). The first sentence may seem to have been somewhat at odds with the managed float. The reason for announcing a band in which the $\mathrm{CNB}$ expected the $\mathrm{CZK} / \mathrm{DM}$ exchange rate to settle was to prevent overshooting at a time when there was no other nominal anchor to tie down exchange rate and inflation expectations, and to limit to the extent possible any passthrough of currency depreciation to domestic inflation.

However, the CNB felt that this approach to monetary policy conduct was not satisfactory and could not continue for much longer. Therefore, on December 21, the CNB Bank Board decided that in the future, monetary programs would be formulated on basis of inflation targeting. The stated purpose of inflation targeting was to provide a nominal anchor

\footnotetext{
${ }^{6}$ For a discussion of the Czech exchange rate crisis see Begg (1998). It is noteworthy that unlike many other emerging market countries that were forced to abandon the currency peg, the Czech koruna depreciated only moderately, and subsequently strengthened again. One reason for this limited depreciation was the relatively low degree of dollarization and currency mismatches in the Czech economy and thus the limited effect of the exit from the peg on companies' and banks' balance sheets.
} 
in the form of an inflation target, to use monetary policy tools directly to achieve the inflation target, and regularly inform the public about the conduct of monetary policy. ${ }^{7}$

In deciding what measure of inflation to target, the CNB faced a trade-off between transparency and the ability to control inflation, an issue that we will look at in detail later. The CNB opted for a compromise that it considered most appropriate for an economy in transition. For the purpose of inflation targeting, it introduced a new concept, so-called net inflation. Net inflation measures changes in the consumer price index (CPI), excluding the movement in regulated prices and is further adjusted for the impact on the remaining items of changes in indirect taxes or subsidy elimination. ${ }^{8}$ Unlike many other inflation-targeting countries, the CNB did not exclude from net inflation changes in prices of energy and agriculture products. Such an exclusion would have narrowed the targeted price index too much, and would make it too detached from the headline inflation. Instead, the CNB subsequently introduced the so-called "exceptions" to deal with this problem (see below).

In choosing whether to target a range or a single numerical value of inflation, the CNB opted for a range. Initially, in 1998 and 1999, it was targeting a band 1 percentage point wide, but from 2000, it widened the band to 2 percentage points. The CNB's decision about the width of the band was guided mainly by its assessment of the accuracy with which it thought it could hit net inflation targets, as well as the past volatility of net inflation.

At the end of 1998, the CNB made some modifications of its inflation targeting strategy. First, the CNB introduced the "exceptions" that could justify missing an inflation target. Exceptions refer to exceptional and unpredictable factors which cause that actual inflation deviates from inflation target, and for which the CNB cannot bear responsibility. These factors are: significant differences between actual and predicted world prices of commodities; significant differences between actual and predicted exchange rate that do not reflect developments of domestic economic fundamentals and monetary policy; significant changes of conditions in agriculture which affect agriculture producer prices; and natural disasters and other extraordinary events that produce demand-led and cost-pushed price shocks (Czech National Bank, 1999, p. 57).

Second, the CNB decided to take a more active role in affecting inflation expectations. It realized that a much more rapid than originally expected decline in inflation in the second half of 1998, together with large degree of rigidity in nominal variables, could

\footnotetext{
${ }^{7}$ The path to inflation targeting for the CNB has many similarities to the path followed by the Bank of England and the Riksbank after the collapse of their exchange rate pegs in 1992. See Bernanke et al. (1999).

${ }^{8}$ At the end of 1997, CPI consisted of 754 items, 91 items had regulated price, and net inflation measured movements of 663 items, which in terms of weighs in consumer basket represented about $4 / 5$ of total basket.
} 
produce undesirable developments in real variables, most importantly, real wages. The CNB therefore initiated an informative meeting with the representatives of trade unions and employees, in order to explain what inflation it expects in 1999, and in this way, to help reduce inflation expectations. ${ }^{9}$

In December 1999, the CNB approved Long-term Monetary Strategy which specified long-term inflation target for 2005. The objective was to make the inflation targeting strategy more forward-looking. Importantly, the CNB made an effort to involve the public and the government in discussion of the long-term monetary policy target. No doubt, this outreach effort reflected the criticism by some politicians that the process of disinflation was too fast and too costly in 1998 and 1999. The CNB did not wish to announce the quantified long-term target corresponding to price stability and the speed with which this ultimate objective is to be achieved, without acquiring the support of the government. The CNB seems to have acknowledged implicitly that the decision on the speed of disinflation is ultimately a political one, and that it had to be taken by a body with political mandate.

Another modification of inflation targeting framework took place in April 2001. At that time, the CNB decided that the main reasons for favoring net inflation targeting rather than headline inflation targeting had disappeared, and it decided that from 2002 on, it would target headline inflation measured by the consumer price index. ${ }^{10}$ The CNB explained that headline inflation covers more comprehensively price developments in the economy, and that it is more relevant for decisions of economic agents. For these reasons, by targeting headline inflation, monetary policy should also be better able to affect inflation expectations. Headline inflation targets for the period 2002-2005 were derived from the trajectory of net inflation specified in the December 1999 Long-term Monetary Strategy. The CNB realized that targeting headline inflation has its risks as well, the most important one being the uncertainty regarding the development of regulated prices and effects of changes in administered prices. For example, the need to achieve a stronger adjustment of fiscal imbalances could require larger than expected increase in administered prices, with consequently larger impact on headline inflation. Another complication could arise from the harmonization of indirect taxes with the EU ahead of the EU entry. But these unexpected effects of changes in regulated

\footnotetext{
${ }^{9}$ Trade unions agreed that it would not be desirable to aim for higher than zero growth in real wages in 1999. The catch was that trade unions' economic experts projected that inflation in 1999 would reach 10 percent, and trade unions therefore demanded a 10 percent increase in nominal wages which in their view would be consistent with zero growth in real wages. As inflation in 1999 remained close to 2 percent, 10 percent nominal wage growth resulted in a large increase in real wages. At the end of 1999, when the CNB was again discussing with the representatives of trade unions inflation prospects for 2000, they seem to have learned from their mistake and expressed more trust in CNB's inflation forecast for 2000.

${ }^{10}$ However, already in 2000, when it announced net inflation target for end-2001, the CNB also began publishing its projection of headline inflation.
} 
prices or administrative measures on headline inflation were included in the exceptions that allow actual inflation to deviate from inflation target without necessitating a monetary policy response. After the April 2001 modification, the list of the exceptions included:

- major deviations in world prices of raw materials, energy-producing materials and other commodities;

- major deviations of the koruna's exchange rate that are not connected with domestic economic fundamentals and domestic monetary policy;

- major changes in the conditions for agricultural production having an impact on agricultural producer prices;

- natural disasters and other extraordinary events having cost and demand impacts on prices;

- $\quad$ changes in regulated prices whose effects on headline inflation would exceed 1-1.5 percentage points;

- $\quad$ step changes in indirect taxes

The CNB has also announced that the list of exceptions could be further widened in the future to include one-time price shocks resulting from the adoption of EU standards.

\section{3.b. Poland}

After the Czech Republic, Poland was the second transition country to introduce inflation targeting. Its approach to inflation targeting differs in some important aspects from the Czech Republic.

As a part of Poland's big bang approach to macroeconomic stabilization, the zloty was pegged to a basket of currencies in 1990. But inflation did not decline sufficiently rapidly, and fixed nominal exchange rate resulted in rapid real appreciation and erosion of competitiveness. Therefore, a preannounced crawling peg was introduced in October 1991. Capital account liberalization led in 1994 and 1995 to large capital inflows, which forced the authorities to widen the crawling exchange rate band in May 1996 to \pm 7 percent. Upward pressure on the currency continued, and in December 1995, the central rate was revalued by 6.4 percent in order to be aligned with prevailing market rate. In early 1998, the NBP began to widen the band again: to \pm 10 percent in February 1998, to \pm 12.5 percent in October 1998, and finally to \pm 15 percent in March 1999. At the same time, the rate of crawl was reduced from an initial 1.8 percent per month in 1991 to 0.3 percent per month. The main reason for the gradual widening of the band was the effort of the NBP to be better able to accommodate large capital inflows.

Poland's transition to an inflation targeting regime began during 1998. As in Hungary, the introduction of inflation targeting was preceded by the amendment of the Act on the National Bank of Poland. This Act specified that the primary objective of the National 
Bank of Poland (NBP) is to maintain a stable price level and simultaneously support economic policy of the Government, provided that this does not constrain the execution of the primary target. The Act also established the Monetary Policy Council (MPC) of the NBP, which replaced the NBP Management Board as the decision-making body. In April 1998, the MPC updated the Assumptions of Monetary Policy for 1998, prepared originally by NBP Management Board in September 1997, and confirmed that the 1998 NBP inflation target of 9.5 percent remained unchanged. ${ }^{11}$ In June 1998, the MPC defined target for monetary policy in 1999, which was to reduce inflation to 8-8.5 percent and began to work on Assumptions of Monetary Policy for 1999, as well as on Medium-Term Monetary Policy Strategy for 1999-2003. These documents were approved in September 1998, and at the same time, the NBP officially announced the introduction of inflation targeting. The NBP also announced at that time the medium-term inflation target for 2003 - reduction of inflation to less than 4 percent. The NBP also informed that from now on, annual inflation targets would be announced in Assumptions of the Monetary Policy.

It should be noted that at the time of announcement to implement inflation targeting, Poland still maintained an exchange rate band which at the time of announcement was widened from \pm 10 percent to \pm 12.5 percent, and later to \pm 15 percent. Only in April 2000 did Poland abandon the exchange rate band and switched to a managed float.

Poland has decided to target the broad consumer price index. The NBP explained that CPI has been used extensively in Poland since the beginning of transition, and that it is deeply rooted in public perceptions as the measure of inflation. The CPI provides accurate information about changes in price levels of consumer goods and services. Application of some measure of core inflation would require eliminating from the targeted index some prices of goods and services that affect strongly public perception of inflationary developments. However, the NBP has started preparatory work for calculating the core inflation index and it did not exclude that it would start targeting core inflation in the future. ${ }^{12}$

Like the Czech Republic, Poland has chosen to target a band rather than a point. Initially, it chose a quite narrow target range, just one half of percentage point, which was subsequently widened to 1.2 points. The NBP explains that before the introduction of inflation targeting, monetary targets in Poland were defined as fixed points, and a wider band could possibly signal to public a weaker commitment to reduce inflation. It could be argued that under such circumstances, a fixed point could be better than a narrow band, as both are

${ }^{11}$ This should be interpreted more as a forecast rather than a full-fledged inflation target.

${ }^{12}$ See National Bank of Poland (1998). It is noteworthy that the NBP intends to calculate the core inflation itself. Usually, central banks targeting a measure of underlying inflation do not calculate this index. In order to avoid a conflict of interest, they let other agencies, mainly statistical office, to calculate and publish underlying inflation. 
unlikely to be hit, and the damage of missing a point could be less serious than the damage of missing a band. However, the NBP did not exclude that it may widen the band in the future.

Unlike the Czech National Bank, the NBP did not define explicitly exceptions that would allow missing the inflation target without requiring the monetary policy response. However, the NBP subsequently analyzed in depth the process of inflation in Poland and the role of monetary and nonmonetary factors (National Bank of Poland (2001), appendix 2). Specifically, the NBP calculates and analyzes different measures of the core inflation. It explains that even though core inflation rates do not replace the headline consumer price index, they provide input for research and analysis, and for decisions on monetary policy.

\section{3.c. Hungary}

The introduction of inflation targeting in the Czech Republic could be characterized as a "big bang" approach. There was a clear break with the past fixed exchange rate regime, and after a few months of technical preparation, a full-fledged inflation targeting regime was put in place. In contrast, Hungary's introduction of inflation targeting could be characterized as "gradualist", even more so than for Poland. ${ }^{13}$

Like other transition economies, Hungary adopted early in transition an exchange rate peg of the forint against the basket of currencies. However, the peg was adjusted downward quite often to maintain external competitiveness. The fluctuation band was gradually widened from \pm 0.5 percent to \pm 2.25 percent, to reduce speculative pressures ahead of the predictable adjustments of the parity. But this mechanism did not prevent large short-term capital inflows in late 1994, and in March 1995, after a devaluation of 8.3 percent, the regime of ad hoc adjustment was replaced with a crawling band. The monthly rate of crawl was initially set at 1.9 percent monthly, but was gradually reduced down to 0.4 percent monthly after October 1999. This regime succeeded in bringing inflation down from about 30 percent in 1995 to below 10 percent in 1999.

Even at the time when the Czech Republic and Poland were abandoning fixed exchange rate regimes, the Hungarian authorities continued to view this narrow fluctuation band as a useful nominal anchor. The band helped reduce inflation and anchor inflation expectations, while at the same time avoiding excessive real appreciation and erosion of competitiveness. However, like other emerging market countries with a fixed exchange rate, Hungary too was ultimately forced to deal with the problems caused by large capital inflows. For some time, Hungary was able to avoid pressure on the narrow exchange rate band because of the presence of controls on short-term capital flows. These controls were effective

${ }^{13}$ Perhaps this is just another example of the gradualist approach of Hungary to economic reforms more generally, unlike the "big bang" or "shock therapy" approach applied in the Czech Republic and Poland. 
in introducing a wedge between onshore and offshore interest rates, providing some degree of independence to monetary policy. But it was clear that as capital controls would be relaxed in line with progression to EU accession, a narrow band regime would become more difficult to sustain.

The problems with the narrow exchange rate band began to intensify in the course of 2000. Inflation, which declined significantly in the period 1995-1999, began to creep up again. While this increase in inflation was initially triggered by external shocks, like higher world oil prices, domestic factors began to play a role as well, including the exchange rate regime. The constraints of the narrow band and increasing capital inflows in 2000 began to make it more difficult for the central bank to pursue simultaneously disinflation and nominal exchange rate stability. Early in 2000, the central bank acted to reduce the pressure on the exchange rate band by cutting interest rates, and it also threatened to introduce capital controls. This strategy worked, and the exchange rate depreciated. However, in a situation of strong economic growth, robust domestic demand and tight labor markets, reducing interest rates did not help much in fighting inflation, which remained relatively high. Periodically, speculative pressures for appreciation and widening of the band appeared, forced the central bank to cut interest rates and/or intervene in foreign exchange market. It opted to do mainly the latter, and it sterilized the liquidity created as a result of these interventions.

However, as the sterilization costs were increasing, it was becoming clear that narrow exchange rate band had outlived its usefulness, and that Hungary needed to introduce more exchange rate flexibility if it was to succeed in reducing inflation further. ${ }^{14}$ In May 2001, the authorities finally decided to widen the fluctuation band around the forint parity against the euro to \pm 15 percent. ${ }^{15}$ The crawling regime was maintained, with the rate of crawl reduced to 0.2 percent monthly, and remaining controls on short-term capital flows were phased out. In October 2001, the crawling peg was completely abolished.

${ }^{14}$ In 2000, inflation ended at 10.1 percent (December to December), much more than the government had projected earlier. In 1999, the government projected that average annual inflation would be 6-7 percent in year 2000. In early 2001, inflation increased further, close to 11 percent. Hungary's ambition to join the EU and EMU as soon as possible had probably contributed to the increasing emphasis on further progress with disinflation that could be accomplished only with a higher degree of nominal exchange rate flexibility, and on the willingness to accept the consequences of a stronger currency for the competitiveness and external balance.

${ }^{15}$ Israel also adopted an inflation targeting regime with a narrow exchange rate band in 1991. Like Hungary, it also found it necessary to widen the exchange rate band, doing so in 1995. Over time, the Israeli's have further downplayed the exchange rate in their inflation targeting regime. For a discussion of Israeli inflation targeting and the role of the exchange rate, see Leiderman (2000) and Bernanke et al. (1999). 
While a wider exchange rate band should allow the government to attach more priority to fighting inflation, as we will discuss below, a conflict between the inflation target and exchange rate target could still arise and complicate the conduct of monetary policy. However, the change in the monetary policy regime has been somewhat confused. At the time when the authorities decided to widen the fluctuation band, they did not immediately announce a shift to a new monetary policy regime. Even though the new exchange rate band was too wide to serve as a useful nominal anchor, the authorities were moving to inflation targeting only gradually. But on July 13, 2001, the new Act on the National Bank of Hungary was enacted by Parliament, which defined the achievement and maintenance of price stability as the prime objective of the National Bank of Hungary. The Act also sought to reinforce $\mathrm{NBH}$ independence, in accordance with the EU requirement.

In its August 2001 Quarterly Inflation report, the NBH explained that for the next couple of years it would be using the inflation targeting system to achieve a gradual reduction of inflation to level corresponding to price stability (National Bank of Hungary, 2001, pp. 35-36). The NBH objective is to meet the Maastricht criterion on inflation in 20042005, so that it could join the EMU in 2006-2007. Specifically, the NBH states that it will seek to bring inflation down to around 2 percent. In agreement with the Government, the NBH set an inflation target of 7 percent for December 2001, 4.5 percent for 2002 and 3.5 percent for 2003 and 2004. In recognition of the fact that the NBH cannot instantly offset unexpected inflationary shocks, it has also established $\mathrm{a} \pm 1$ percent tolerance band around the announced disinflation path.

The primary instrument that the NBH uses to attain its inflation targets will be changes in its benchmark interest rates. The NBH has particularly emphasized the important role of changes in exchange rate on inflation. It argues that in Hungary, the exchange rate channel is the central bank's most powerful and fastest means of influencing domestic prices. (However, we will see later in Section 5 that this reasoning may be dangerous.) While the exchange rate will not have the same prominent role as during the narrow-band regime, and the NBH will be less able to control its short-term movements, it will continue to play an important role. The NBH has indicated that it would try to influence the exchange rate in order to achieve the desired inflation outcome. In order to achieve the changes in exchange rate, it will use mainly changes in interest rates, while direct intervention in foreign exchange market will be used only exceptionally, to deal with the emergency situations. The NBH recognizes that in the short-term, the actual exchange rate could deviate from an exchange rate path that would be consistent with the disinflation path. All in all, exchange rate movements seem to play a much more important role in Hungary than in other inflation targeting countries. Such explicit emphasis of the role of exchange rate movements in achieving inflation targets as seen in Hungary is quite unique.

The NBH estimates that it takes up to one and half year for changes in interest rates to have a full impact on inflation. It argues that if it would try to keep inflation in line with the targeted path over the short-term horizon, the result could be excessive volatility of output (and arguably also excessive instrument volatility). Therefore, it would confine policy 
responses only to deviation of forecasted inflation from targeted inflation over the horizon of 1 to 1.5 years.

The transparency of this new system should be enhanced by the publication of NBH's inflation projections every quarter for the following six quarters. Moreover, the NBH will also publish its considerations that were behind its monetary policy decisions, and its analysis of the achievement of inflation target. Quarterly Report on Inflation contains also the projection of inflation using a fan chart.

Unlike the $\mathrm{CNB}$, the NBH began to target headline inflation immediately. But there is no discussion in NBH official documents about the reasons for choosing to target headline inflation rather than adjusted or underlying inflation. The NBH also did not specify any exceptions that would justify a deviation of actual inflation from its inflation target, though there is some discussion in its inflation reports about the possible extent of price deregulation and their effects on headline inflation. When announcing the introduction of inflation targeting, the NBH was also silent about the possible conflict between the exchange rate band and the inflation target.

Overall, the impression is that the NBH has focused less on operational aspects of the inflation targeting regime than has the CNB or even the NBP. Perhaps this reflects the fact that the NBH officials still attach importance to the nominal exchange rate band as an important anchor of the economy. They seem to believe that moving the exchange rate within the band will help them to achieve long-term inflation target which will allow them to qualify for the EMU. In a sense, this strategy could be understood: why invest heavily in a detailed design of policy framework that will anyway be removed in a few years after Hungary adopts the euro? The Czech Republic and Poland introduced inflation targeting much earlier, and they may also be less eager to join the EMU as soon as possible. This means that inflation targeting could be in place for a longer time, and that a well-designed inflation targeting framework was more necessary.

\section{Preliminary experience with inflation targeting}

In view of the relatively short period during which inflation targeting has been implemented in the transition economies, it is too early to make a definitive judgment about the experience with the operation of this new policy framework. Nevertheless, some preliminary observations could be made. There are two ways in which we can evaluate the experience with inflation targeting in transition economies.

First, we can look how successful were inflation targeting central banks in achieving inflation rates close to their inflation targets. Here, the answer is "not all that well". Initially, the CNB has several times significantly undershot its inflation target, while the NBP has first overshot it and subsequently undershot it. The NBH has hit its targets in 2001 and 2002, but its short experience with inflation targeting does not tell us much yet. But even this short- 
term experience brings one thing clear, namely the problems of targeting simultaneously inflation and exchange rate in a world of free capital flows.

Second, we can examine the success of inflation targeting in reducing inflation. Looking only on the success in hitting their inflation targets could be a too narrow perspective for assessing the performance of inflation targeting. All central banks in inflation-targeting transition economies have emphasized that the main purpose of inflation targeting framework is to allow these countries to bring inflation down to a level that would allow them to qualify for EMU membership. When we evaluate inflation targeting from this perspective, the preliminary experience with this regime should be judged more positively: all three countries are proceeding well with disinflation, and there is a good chance that in a few years, they should be able to reach price stability, as defined for the purpose of EMU qualification. However, the process of disinflation is not a smooth one, and there are quite large variations in inflation.

Let us now look in more detail on the record of implementation of inflation targeting in the three analyzed countries. First, we will discuss the speed of disinflation implied by announced inflation targets, and then we will examine how successful the inflation targeting countries were in hitting these targets.

\section{4.a. Inflation targets and the speed of disinflation}

In many advanced economies that pursue inflation targeting, this regime has been introduced only after price stability has been reached (Bernanke et. al. (1999)). But this was not the case in the transition economies where at the time of introduction of inflation targeting, inflation was still running well above the level considered consistent with price stability. Therefore, the authorities in these countries had to make two decisions: (1) to quantify inflation target that would be compatible with the long-term objective of price stability; and (2) to decide on the time horizon within which this ultimate objective is to be met, that is, to decide on the speed of disinflation.

There is extensive literature discussing how to quantify price stability. In the literature, we can find several arguments why central banks should not quantify price stability as inflation at zero or near zero (in the range of $0-1$ percent). One reason, relates to downward nominal wage rigidity. If the inflation rate were to approach zero under the condition of downward wage rigidity, it would be difficult to achieve real wage adjustment in response to changed market conditions, such as a negative demand shocks. The result could be higher real wages than is desirable, higher unemployment and lower economic growth. ${ }^{16}$ A second reason relates to the

${ }^{16}$ This mechanism is described in Akerlof et al. (1996), but it is highly controversial because the evidence that low inflation leads to a rise in unemployment is very mixed. In addition while as pointed out in Groshen and Schweitzer $(1996,1999)$, inflation can not only put

(continued) 
impossibility of reducing nominal interest rates below zero, which means that if inflation is close to zero, real interest rates cannot be pushed below zero when this might be necessary in order to stimulate economic activity. ${ }^{17}$ Furthermore, a zero inflation target may lead to periods of deflation which could promote financial instability and make it harder to conduct monetary policy because interest rates would no longer provide a useful guide to the stance of monetary policy (Mishkin and Schmidt-Hebbel (2002)).

In the literature, one can observe a convergence of views that an inflation rate of 1-3 percent corresponds to price stability (Table 2). If we look at how central banks quantify price stability in practice, we see that there is not much difference between the theoretical conclusions and what the central banks actually do. This is the case for all economies -developed, developing and transition ones.

\section{Table 2. Inflation targets}

\begin{tabular}{|l|l|l|}
\hline Country & Targeted inflation in $\%$ & Period \\
\hline Czech Republic & $1-3(2-4) 1 /$ & 2005 \\
\hline Australia & $2-3$ & Average during a business cycle \\
\hline Brazil ${ }^{18}$ & $2-6$ & 2001 \\
\hline Chile & $2-4$ & 2001 \\
\hline Poland & $<4$ & 2003 \\
\hline Hungary & Around 2 & $2004-2005$ \\
\hline Mexico & 3 & 2003 \\
\hline Izrael & $3-4$ & 2001 \\
\hline New Zealand & $0-3$ & From 1996 \\
\hline Canada & $1-3$ & From 1995 \\
\hline Euro area & $<2$ & From 1999 \\
\hline United Kingdom & 2.5 & From 1996 \\
\hline
\end{tabular}

Source: Andrea Schaecher aj. (2000); web sites of Banco de México, http://www.banxico.org.mx/, National Bank of Hungary, http://www.mnb.hu/, and European Central Bank, http://www.ecb.int/.

1/ 1-3 percent is for net inflation, 2-4 percent for headline inflation.

"grease" in the labor markets as Akerlof. et. al argue, but can also put in "sand" that makes the labor markets less efficient.

${ }^{17}$ This argument has been made in Summers (1991).

${ }^{18}$ For 2002, the target was subsequently set at 2.5-4.5 percent, but as a result of the debt crisis and sharp currency depreciation, inflation in 2002 has reached 12.5 percent. In response to higher inflation, the central bank has also raised its 2003 and 2004 targets. 
However, some have raised the quesiton whether the specific conditions of transition economies would not justify targeting somewhat higher inflation than in developed economies. High growth countries typically experience real exchange rate appreciation by an amount proportional to the relative difference of traded to non-traded sector productivity growth relative to the rest of the world (the Harrod-Belassa-Samuelson effect). If it is appropriate for these countries to aim at traded goods inflation similar to industrialized countries in the long run, then trend real appreciation requires a domestic non-traded goods inflation that is somewhat higher and so the inflation rate should be slightly higher than it would be desirable for averagegrowth countries. Škreb (1998) notes that in the transition economies, it is particularly difficult to measure precisely the improvements in the quality of goods. As a result, actual inflation could be much lower than measured inflation. Because of these measurement problems, as well as other reasons, Škreb argues that in transition economies, inflation in the range of 4-5 percent would correspond to price stability.

Other authors argue, however, that during the convergence with the developed economies, transition economies should be expected to experience a rapid growth of labor productivity from implementation of economic reforms, which should produce lower inflation (Deppler, 1998). Clinton (2000) argues that rapid productivity growth in transition economies weakens the traditional arguments in favor of a notably higher than zero inflation rate. Given the rapid growth of labor productivity, a decline in nominal wages would rarely be needed. ${ }^{19}$ Similarly, given the high real return on capital and high trend economic growth, it is not very likely that a situation would arise in which a central bank would have to stimulate an economy in recession with the help of negative real interest rates.

What can be said about the speed of disinflation? Theoretically, disinflation could be too quick, resulting in excessively large (though, arguably temporary) loss of output and higher unemployment, or it could be too slow, inflation expectations could become more entrenched at high level, and this would make it more costly to reduce inflation later. ${ }^{20}$ Therefore, it could be argued that there exists an optimal speed of disinflation which would minimize the sacrifice ratio (the ratio of loss of output to disinflation). ${ }^{21}$ However, the

${ }^{19}$ One problem with this argument is that the rapid productivity growth applies economywide, but there could still be firms or industries where productivity growth would be small or negative, and where decline in nominal wages would be called for if inflation would be close to zero.

${ }^{20}$ It could be argued that lower inflation means usually higher output growth, and therefore, the sooner lower inflation is reached, the sooner will the economy achieve a higher output growth. But there are also counterarguments. For example, due to a loss of marketable skills, persons that could be seen as temporary unemployed during the period of rapid disinflation could become permanently unemployed, which results in an additional loss of output.

${ }^{21}$ For a discussion of the costs of disinflation see Ball (1994). The author comes to the conclusion that fast disinflation reduces the sacrifice ratio. 
determination of this optimal speed of disinflation is less a matter of exact science, and more a matter of judgment.

In the literature, a number of factors have been identified that affect the sacrifice ratio, that is, the output effect of disinflation. These include the structure of the economy, the degree and the way of indexation of wages and other nominal variables, past history of inflation and stabilization, credibility of monetary policy, the degree of openness of the economy etc. Furthermore, as has been shown in the case of other countries, change in inflation is positively correlated with the level of economic activity (Stock and Watson, (1999)). Given the fact that economic reasoning does not provide a hard conclusion about the optimal speed of disinflation, and in view of the important consequences of the decision about the speed of disinflation for the economy and for different groups of population, societies pay particular attention to the mechanism how this decision is reached. By its nature, the decision about the speed of disinflation is not a purely technocratic decision that could be put solely in the hands of professional economists or central bankers. Because different speeds of disinflation will have different consequences for different groups of population, this decision is by its nature a political decision, and thus an argument can be made for entrusting it to a political body that has a political legitimacy to make such political choices. This has implications for the debate on optimal degree of central bank independence that is discussed in Section 5.

However, for transition countries in Central and Eastern Europe, the desire to join at some point in the future EMU is of more practical relevance for monetary policy and the theoretical arguments about the appropriate quantification of price stability and the optimal speed of disinflation. Eventual EMU accession will depend on the ability to meet the Maastricht criteria including low inflation, and the decision to join the EMU at a certain date will thus implicitly contain a decision on how quickly and how far disinflation will have to go.

At this stage, all three countries that we examine have expressed a commitment to join the EMU, even though they may choose a different speed with which to move from joining the EU to joining the EMU. But notwithstanding this possible different speed, all three countries are committed to a relatively fast disinflation. Table 3 summarizes the speed of disinflation implied by the level of inflation at the time of the introduction of inflation targets and by the long-term inflation objective.

Table 3. The speed of disinflation $1 /$

\begin{tabular}{|l|l|l|l|l|l|l|}
\hline & $\begin{array}{l}\text { End-1997 } \\
\text { inflation }\end{array}$ & $\begin{array}{l}\text { Introduction } \\
\text { of IT }\end{array}$ & $\begin{array}{l}\text { Inflation at } \\
\text { that time }\end{array}$ & $\begin{array}{l}\text { Direction } \\
\text { Of inflation }\end{array}$ & $\begin{array}{l}\text { Ultimate } \\
\text { Objective }\end{array}$ & $\begin{array}{l}\text { Year to be } \\
\text { Achieved }\end{array}$ \\
\hline CR & 10.0 & Dec 97 & 10.0 & Rising & $2-4$ & 2005 \\
\hline Hungary & 18.4 & Aug 01 & 8.7 & Falling & Around 2 & $2004-5$ \\
\hline Poland & 13.2 & June 98 & 12.2 & Falling & $<4$ & 2003 \\
\hline
\end{tabular}




\section{1/ All inflation figures refer to CPI}

As we can see, the ultimate objective is defined in each country in a different way: as a range in the Czech Republic (both upper and lower band is specified); as a maximum ceiling in Poland (only upper band is specified), and as a "soft" point target in Hungary (no lower and upper bound specified, but inflation should meet the Maastricht criterion). This also means that one single inflation rate could meet all these constraints at the same time.

Even though the Czech Republic did not reveal a firm intention to choose the fastest possible strategy to join the EMU, the CNB has still opted for a relatively quick disinflation so that it would be able to meet the Maastricht criterion and eventually move quickly to the EMU membership if it chooses to. Figure 1 shows the CNB's actual and inflation targets. When the inflation targeting framework was adopted in December 1997, inflation was 10 percent, and it continued to rise, to about 13 percent in early 1998 (in CPI terms; net inflation approached 8 percent). The CNB decided that at the end of 1998, net inflation should decline to 5.5-6.5 percent; and at the end of year 2000, to 3.5-5.5 percent. In December 1999, the CNB quantified its long-term objective of price stability: net inflation in the range 1-3 percent in 2005, which was subsequently complemented by setting the 2005 CPI target in the range 2-4 percent. Given the inflation target for the year 2000 in the range of 3.5-5.5 percent, this implied an average annual reduction in net inflation by 0.5 percentage points. The CNB explained that this long-term target would basically imply a continuation of the existing pace of disinflation. However, in December 2002, CPI inflation fell to 0.6 percent, which already brought it well below the long-term target range.

In Poland, the NBP first set a short-term inflation target in June 1998 for end-1999 in the range of 8-8.5 percent (see Figure 2). At the time of the announcement of the inflation target, inflation was above 12 percent, and declining. In September 1999, the NBP also announced the medium-term target of CPI inflation of less than 4 percent at the end of 2003. Subsequently, inflation continued to fall faster that expected, and in March 1999, when it fell to around 6 percent, the NBP modified the end-1999 CPI target to 6.6-7.8 percent. In September 1999, in Monetary Guidelines for the Year 2000, the NBP set end-2000 inflation target in the range 5.4-6.8 percent. However, the process of disinflation in Poland was interrupted, as inflation increased from 5.6 percent in February 1999 to 11.6 percent in July 2000. Therefore, the 2001 inflation target was set higher than in 2000, 6-8 percent, but the targeted inflation range for the end-2002 was reduced to 4-6 percent. As inflation at the end of 2001 fell to 3.6 percent, meeting this target would have required another mild pick-up in inflation. But instead, inflation in 2002 fell rapidly and in December 2002 reached 0.8 percent, resulting in another significant undershooting of the target. Right now, inflation in Poland is below the NBP long-term objective. 
Hungary launched official inflation targeting only in mid-2001. ${ }^{22}$ At that time, inflation was already declining: from a peak of 10.8 percent in May 2001, it fell to 8.7 percent in August when details of the new inflation targeting regime were published in the Quarterly Inflation Report (see Figure 3). For 2001, the inflation target was set in the range 6-8 percent. For 2002, inflation target was set at 3.5-5.5 percent, and for 2003, the target was

set at 2.5-4.5 percent. ${ }^{23}$ The long-term NBH's objective is that Hungary meets the Maastricht criterion on inflation in 2004-2005, which should be possible with inflation even slightly higher that 2 percent that the NBH seeks to achieve in long-term. Unlike the Czech Republic and Poland, Hungary also specified its long-term inflation target qualitatively, in terms of meeting the Maastricht criterion for inflation, thus underscoring its preference to join EMU sooner rather than later. As inflation in December 2002 was 4.8 percent, meeting the longterm inflation target would likely require stabilizing inflation slightly below present level, in contrast to the Czech Republic and Poland, where inflation is likely to pick-up somewhat from present unsustainable low levels.

\section{4.b. Hitting and missing inflation targets}

In the previous part, we have examined the experience with inflation targeting from the perspective of disinflation. In this section, we look at how successful the three countries were in meeting their inflation targets. In this respect, we should keep in mind that countries could be quite successful, in the longer-term, in bringing inflation down, but if a successful disinflation is accompanied by a significant instability of inflation (as evidenced by repeated large undershooting or overshooting of inflation targets), this could be costly for the economy as well.

There is not yet much we can read from the history of inflation targeting in Hungary because it is so recent (see Figure 3). The 2001 target was announced only in August 2001, and it therefore was more a short-term inflation forecast that actual inflation target.

Therefore, the fact that Hungary has met this target and the 2002 target does not tell much about the operation of inflation targeting framework. ${ }^{24}$ The inflation target for 2002 implied a

\footnotetext{
${ }^{22}$ The NBH was publishing inflation objectives based on Government budgetary projections for 1998, 1999 and 2000 (12-13 percent, 9 percent and 6-7 percent respectively), but these were not formal inflation targets and there was no formal requirement for the NBH to meet them (see Siklos and Ábel (2001)).

${ }^{23}$ The long-term inflation target and the 2002 target were announced in the August 2001 Inflation Report, while the 2003 target was announced in the press on December 2001, when the government agreed with the NBH's proposal.

${ }^{24}$ It will be interesting to watch how inflation targeting will operate in 2003 , as the potential conflict between the inflation target and exchange rate target will come to the fore and as markets already expect the 2003 inflation to exceed the 2003 NBH target.
} 
fairly rapid disinflation, alongside the trend started in mid-2001. In 2001 and 2002, disinflation was helped by the appreciation of the forint. However, since the forint has reached the upper end of the fluctuation band and the government seems to resist the revaluation of parity, there is no room for further nominal appreciation that would assist in further disinflation.

Table 4 and Figures 1 and 2 show the history of inflation targeting in the Czech Republic and Poland tell a very different story. In the Czech Republic, the CNB significantly undershot its inflation targets, particularly in 1998 and 1999, and less in 2000. Net inflation fell to 1.7 percent at the end of 1998 and to 1.5 percent at the end of 1999 , well below the CNB's targets. Only in 2001, in the fourth year of inflation targeting, did the CNB succeed in achieving its inflation target, but it undershot its target again in 2002.

Table 4. Targeted and actual inflation in Czech Republic and Poland

\begin{tabular}{|l|l|l|l|l|}
\hline & \multicolumn{3}{|l|}{ Czech Republic (net inflation) } & \multicolumn{2}{l|}{ Poland (headline inflation) } \\
\cline { 2 - 5 } & Target & Actual & Target & Actual \\
\hline 1998 & $5.5-6.5$ & 1.7 & X & 8.6 \\
\hline 1999 & $4-5$ & 1.5 & $6.4-7.8(8-8.5) 1 /$ & 9.8 \\
\hline 2000 & $3.5-5.5$ & 3 & $5.4-6.8$ & 8.5 \\
\hline 2001 & $2-4$ & 2.4 & $6-8$ & 3.6 \\
\hline 2002 & $2.75-4.752 /$ & 0.5 & $4-6$ & 0.8 \\
\hline
\end{tabular}

Source: Czech National Bank, National bank of Poland

$1 /$ Initial target in brackets

2/ Headline inflation

As we can see in Figure 2, in Poland there was an opposite problem, as the NBP significantly overshot its targets in 1999 and 2000. In the course of 1998, inflation in Poland was falling rapidly, and at the end of the year, it fell to 8.6 percent, less than the 9.5 percent projected. A more rapid than expected decline in inflation prompted the NBP to reduce early in 1999 its target for end-1999, from 8-8.5 percent to 6.4-7.8 percent, a step which in retrospect may seem to have been somewhat premature. If the NBP maintained its original target 8-8.5 percent, it would have missed it only by a very small margin. But in the course of 1999, inflation began to increase again, and the 1999 target was missed by a significant margin, as was the 2000 target. Very tight monetary policy and slowing economic activity helped to bring inflation down sharply in 2001, and subsequently, the 2001 and 2002 targets were undershot quite sizably.

These repeated large deviations of actual inflation from inflation target would seem to suggest that inflation targeting was not very successful in the Czech Republic and Poland. But before we make any definitive judgments about the success or failure of inflation targeting in these two countries, it is important to understand the reasons for such significant 
deviations of actual from targeted inflation. We have to examine more closely both domestic and external economic circumstances that have prevailed during this period, and that have affected actual inflation.

At the time when the CNB launched inflation targeting, inflation was rising quite rapidly, but at the same time, the economy was already slipping into a prolonged recession. The 1998 and 2000 inflation targets were specified at the time when the CNB (and other public and private forecasters) expected much stronger economic growth than actually materialized. ${ }^{25}$ However, with the onset of a major banking crisis in 1997-98, economic activity fell and contributed to a much faster disinflation than envisaged by CNB's inflation targets. ${ }^{26}$ Moreover, the $1997-$ 1998 financial crises and weak global economic activity contributed to falling commodity prices, including energy prices. ${ }^{27}$ The CNB calculations suggest that these external factors had a sizeable effect on net inflation: in 1998, these factors reduced net inflation by 2-3 percentage points (", apek (1999), p. 9). In the absence of these shocks, net inflation at the end of 1998 would probably have been close to the bottom of the target range. There were also other structural shocks that contributed to lower than projected inflation. Among the more important was the continuing unexpected decline in foodstuff prices in 1998 and 1999. Ex post, the decline in foodstuff prices was ascribed to the struggle of the retail distributors for market share in the Czech market. Weak domestic demand, together with strong koruna and strong competitive pressure in the domestic economy resulting from penetration on the Czech market of foreign distributors continued to keep inflation low even after the effects of external price shocks began to disappear In addition, the decision not to exclude energy prices and exclude adjustment of regulated prices from the targeted price index did not achieve its objective of encouraging the government to pursue a "courageous policy of price deregulation", as the CNB initially hoped.

When inflation targeting was introduced, Poland was facing very different economic circumstances than the Czech Republic. First, the implications of global developments for

${ }^{25}$ For example, the May 1998 World Economic Outlook projected real GDP growth in 1998 of 2.2 percent. This forecast was quite accurate, but with an opposite sign. Actual growth was -2.2 percent.

${ }^{26}$ Of course, the hotly debated question was whether and to what extent the CNB's excessively tight monetary itself contributed to slower than projected growth.

${ }^{27}$ In U.S. dollar terms, oil price fell by 31.2 percent, while nonfuel commodity prices fell by 14.7 percent in 1998. See International Monetary Fund (1999). It should be noted that this effect of financial crises contributed to an unexpected fall in inflation worldwide. The May 1997 IMF World Economic Outlook projected that in 1998, consumer prices in advanced economies would increase by 2.5 percent, while the actual increase was only 1.5 percent. 
domestic inflation were better known to the NBP at that time, and could be incorporated into the inflation target. Like in the Czech Republic, inflation in Poland has declined significantly during 1998 and 1999, but this decline was less dramatic, and did not last as long. Already in the second half of 1999, inflation in Poland began to exceed by increasingly wider margin inflation in the Czech Republic (see chart 1). Relatively rapid economic growth of domestic demand, increase in import prices and monopolistic structure of some industries together resulted in the reversal of disinflation in Poland in the course of 1999. Fiscal policy was also much more expansionary than the NBP has expected, and this expansionary stance further fueled domestic demand.

The NBP responded to these developments by a significant tightening of monetary policy, and it continued to keep monetary conditions very tight even when inflation began to fall sharply later in 2000 and in 2001. This - to some excessively - tight monetary policy also brought economic growth nearly to a halt by the end of 2001, and contributed to increased tension between the NBP and the government, which even led by the end of 2001 to threats of reduction of NBP independence. It appears that the NBP tried to use a tight monetary policy stance as an instrument to force the government to strengthen structural fiscal balance, even at the cost of significant undershooting of its inflation target.

Judging from the success in meeting its inflation target, the NBP has not been very successful thus far. In the first two years, inflation targets were overshot, and in the third and fourth years, there was a significant undershooting. Recent years saw a significant instability of inflation, which was falling rapidly from 17.8 percent in the beginning of 1997 to 5.6 percent in February 1999, then rose to 11.6 percent in July 2000, and fell again to 0.8 percent in December 2002. In Poland, external factors may have been of less importance in explaining the failure to meet inflation targets than in the Czech Republic, while the conduct of macroeconomic policy has probably mattered more. First, unexpected fiscal expansion, combined with easy monetary policy, contributed to the acceleration of inflation and overshooting of inflation targets; and subsequently, sharp tightening of monetary policy, in the absence of further easing of fiscal policy, reduced inflation sharply down and produced a significant undershooting of the target.

\section{4.c. Comparison of Inflation and Output Performance of inflation targeters with other transition countries}

We have seen above that hitting inflation targets has not been an easy exercise. However, this may have been unavoidable given the shocks the inflation targeters were subjected to. To access the success of inflation targeting in transition countries, we have to ask how well the inflation targeters have done relative to the non-targeters?

There are two alternative monetary policy regimes to inflation targeting that transition countries have chosen: 
1. exchange rate peg: a crawling peg for Hungary until August 2001, a standard peg for Latvia (peg to SDR) and a hard peg of the currency board type for Bulgaria, Estonia and Latvia.

2. float without an inflation target: Slovakia, Slovenia and Romania. ${ }^{28}$

Figures 4 and 5 compare inflation rates (year over year) in the Czech Republic and Poland with the other transition countries. A relevant starting date for comparing the different monetary regimes is December 1998 (marked in the figures) which corresponds to the first date that inflation targets were to be met in the Czech Republic. As we can see in Figure 4 which has a comparison with the non-inflation targeting floaters, the Czech Republic and Poland have experienced lower levels of inflation for most of the 1999-2002 period than have the non-inflation targeting floaters. On the other hand, Figure 5, which has a comparison with the exchange rate peggers, does not display a clear dominance of inflation targeting over pegging. Hungary with its soft peg and Bulgaria with its currency board have typically had higher inflation rates than the Czech Republic and Poland, but Lithuania with currency board and Latvia with its standard peg have experienced lower inflation rates. Estonia has had inflation rates comparable to those in the Czech Republic, but up until the last half of 2002, has had lower inflation than Poland.

Clearly a low level of inflation is only one measure of success of monetary regimes equally important is the variability of inflation and output. Table 5 provides the standard deviation of both inflation and output for the period 1999-2002. Here we see that the Czech Republic and Poland are in the middle of the pack on both criteria. The Czech Republic and Poland have higher standard deviations of inflation than the hard pegging, Baltic countries, while they have lower variability than Hungary, a soft pegger, Bulgaria, a hard pegger, and Slovakia and Romania, non-inflation targeting floaters. Slovenia, a non-inflation targeting floater, has equal inflation variability to the Czech Republic, but has lower variability than Poland.

Although, we should not make too much of the data in Figures 4 and 5 and Table 5 because it is over such a short period and because these countries have been subjected to different shocks, it is worth noting in terms of inflation control, inflation targeting does not clearly dominate the other monetary policy regimes chosen by transition countries.

We reach a similar conclusion in terms of output variability as seen by the standard deviations of output growth reported in Table 5. ${ }^{29}$ The Czech Republic and Poland have had

${ }^{28}$ Currency regimes of these countries are characterized as managed floats. In June 2001, Romania's currency regime was reclassified from a managed float to a crawling band because the central bank intervenes to prevent currency appreciation.

${ }^{29}$ The mixed results reported here on the performance of inflation targeting regimes relative to other monetary policy regimes is not very surprising. As argued by Calvo and Mishkin (2003), the choice of monetary policy regime is likely to be less important to the

(continued) 
lower standard deviations than the hard peggers, Bulgaria and the Baltic states, but have had higher standard deviations than Slovakia and Slovenia, non-inflation targeting floaters. Hungary, a soft pegger for most of the period has had the lowest standard deviation of output growth of all the countries in the table. However, even less should be made of these comparisons because real shocks have differed dramatically across the transition countries. For example, as we can see in Figure 6, the Baltic countries, which have a higher proportion of their trade with Russia as a result of their having been part of the former Soviet Union, suffered very dramatic output declines in 1999 in the aftermath of the Russian financial crisis in the fall of 1998. The contraction of the Russian economy at that time would have had a far smaller impact on transition countries which were less integrated with Russia and whose trade was mostly with Western Europe.

Table 5. Inflation and Output Growth Volatility: 1998-2002

\begin{tabular}{|l|l|l|}
\hline & Inflation volatility & Output volatility \\
\hline Czech Republic & 3.49 & 2.00 \\
\hline Poland & 3.6 & 1.82 \\
\hline Hungary & 3.08 & 0.72 \\
\hline Estonia & 3.08 & 3.07 \\
\hline Latvia & 1.34 & 2.52 \\
\hline Lithuania & 2.18 & 3.5 \\
\hline Bulgaria & 49.7 & 3.97 \\
\hline Slovakia & 3.88 & 1.39 \\
\hline Slovenia & 1.34 & 0.82 \\
\hline Romania & 18.37 & 4.83 \\
\hline
\end{tabular}

\section{Lessons and problems of inflation targeting in transition economies}

Even though the experience with the implementation of inflation targeting in transition economies is relatively short, it has nevertheless brought out several specific issues, which deserve discussion. First, how should the standard operational aspects of inflation targeting be specified: i.e., what price index should be targeted? should the inflation target be a point or a range? and what should the horizon for the target be? Second, given the fact that transition economies began inflation targeting in a situation of higher inflation than the long-term objective, how should the speed of disinflation be determined, and closely related, how should the government be involved in setting inflation targets?

macroeconomic performance of emerging market and transition countries than deeper institutions. 
Third, how should monetary policy respond to the deviation of the actual inflation from the targeted disinflation path and how much should the floor of an inflation target be emphasized relative to the ceiling? And fourth, how should the exchange rate be incorporated into the inflation targeting framework?

\section{5.a. Operational aspects of inflation targeting}

What measure of inflation to target? In deciding what measure of inflation to target, central banks face a trade-off between transparency and the ability to control inflation. The advantage of a broadly defined headline inflation (i.e. the consumer price index) is that it is better understood by the public. However, the problem is that headline movements could reflect factors other than monetary policy measures. A more narrowly defined measure of inflation that excludes possible effects of transitory shocks could be better controlled by a central bank, but at the same time, it could be more difficult for the public to assess the conduct of monetary policy on basis of such measure. Given the emphasis on central banks' accountability and transparency in a regime of inflation targeting, this could potentially be a serious handicap, particularly for a central bank that still has to earn its credibility.

The CNB opted for a compromise that it considered most appropriate for an economy in transition. For the purpose of inflation targeting, it introduced a new concept, so-called net inflation which excluded regulated prices (see section $3 a$ ). Specific conditions of economic transition have played an important role in selecting net inflation as the targeted measure of inflation. Unlike in industrial countries, many prices were still regulated in the Czech Republic in late 1997. The CNB knew that substantial changes in these regulated prices, including rents, would be needed before they reached a market-clearing level. As a result, a given monetary policy stance could produce different future paths of headline inflation, depending on the pace of price deregulation or the size of adjustment of administered prices. At the same time, this approach was supposed to avoid a situation where government would be hesitant to pursue a faster adjustment of regulated prices out of concern that inflationary effects of such policy would force the CNB to tighten monetary policy, with adverse effects on economic growth, exacerbating thus the political cost of deregulation. Indeed, the former Acting Governor of the CNB Pavel Kysilka stated that "by targeting net inflation, we have provided a room to the government to pursue a courageous policy of price deregulation." (Kysilka (1998), pp. 10-12). Obviously, a high share of regulated prices in total CPI does not make it easier for the central bank to deal with this trade-off between transparency and ability to control inflation. ${ }^{30}$

\footnotetext{
${ }^{30}$ The Czech economy is very open, with imports representing about 50 percent of GDP, and changes in import prices of oil and gas have large impact on domestic prices. However, at the time of the introduction of inflation targeting, the CNB had considered isolating the effects of price deregulation as more important than isolating the effects of terms-of-trade shocks or exchange rate effects.
} 
Subsequently, the pace of price deregulation and increase in administered prices was less than the CNB had hoped and so use of the net inflation construct did not produce the desirable outcome the CNB expected. In addition, the net inflation construct turned out to be more volatile than headline inflation, helping to contribute to larger misses of the target. When it decided to target net inflation, the CNB did not exclude that in the future, it could modify the measure of targeted inflation. The problems with the net inflation measure thus led the CNB to abandon it in April 2001, and it subsequently moved to targeting headline inflation as has been discussed in section $3 \mathrm{a}$.

Target a point or a range? As in other aspects of design of the operational framework, there is a trade-off involved in deciding about the width of the band. A wider band increases the chance that monetary policy will be successful in keeping targeted inflation inside. But a too large band could reduce the ability of inflation targeting to anchor inflation expectations, and it could be of less help in establishing the antiinflationary credibility. Some argue that a band that is narrow enough to anchor inflationary expectations is likely to be frequently missed, and that it is preferable to target a point and explain the deviations of actual inflation from that point target (Bernanke et al (1999) and Mishkin (2001)).

In a sense, one can argue that higher degree of uncertainty in projecting inflation and correspondingly higher probability that even a target range would be missed makes the issue of point versus range less of an issue than in more advanced inflation-targeting economies. By setting a range, the central bank may indicate what is its estimate of uncertainty of reaching the inflation target. This is how the CNB has explained its decision regarding the width of the targeted range. Missing a target range then carries a larger risk of credibility loss than missing a target point. Targeting a reasonably narrow band (that is, narrow enough so that it provides a sufficient nominal anchor) does not make much sense when the probability that it would be missed is not significantly less than the probability of missing a point.

Time horizon of inflation targeting. Monetary policy affects the economy and particularly inflation with long lags. In industrialized countries, lags from monetary policy to inflation are typically estimated to be on the order of two years. Shorter time horizons, such as one year can be highly problematic. The first problem with too short a horizon is that it can lead to a controllability problem: too frequent misses of the inflation target, even when monetary policy is being conducted optimally. The second problem is that it can lead to instrument instability, in which policy instruments are moved around too much in order to try to get inflation to hit its targets over the shorter horizon. A third problem is that too short a horizon implies that not enough weight is put on output fluctuations in the central bank's loss function. ${ }^{31}$

\footnotetext{
${ }^{31}$ As demonstrated by Svensson (1997), a faster target path of inflation to the long-run inflation goal implies a smaller weight on output variability in the central bank's loss function.
} 
The experience with inflation targeting in New Zealand documented in Bernanke et al (1999), illustrates these problems. In 1995, the Reserve Bank of New Zealand overshot its oneyear-horizon inflation target range, making the governor subject to dismissal under the central banking law. It was recognized in the Reserve Bank that the overshoot was likely to be shortlived and inflation was likely to fall, indicating that monetary policy had not been overly expansionary. Fortunately, this view was accepted outside the Bank and the governor, Don Brash, whose performance was excellent, retained his job. Attempting to hit the annual target did, however, have the unfortunate consequence of producing excessive swings in the monetary policy instruments, especially the exchange rate. In a small, open economy, like New Zealand, exchange rate movements have a faster impact on inflation than interest rates. Thus trying to achieve annual inflation targets required heavier reliance on manipulating exchange rates which led to its having large swings. By trying to hit the short-horizon target, the Reserve Bank also may have induced greater output fluctuations. For example, the Reserve Bank pursued overly tight monetary policy at the end of 1996 with the overnight cash rate going to $10 \%$ because of fears that inflation would rise above the target range in 1997, and this helped lead to an undesirable decline in output. The Reserve Bank of New Zealand has recognized the problems it had with a too short target horizon and now emphasizes a horizon of six to eight quarters in their discussions of monetary policy (Sherwin (1999) and Drew and Orr (1999)). Furthermore, the Policy Target Agreement between the central bank and the government has recently been amended to be more flexible in order to support the longer policy horizon (Reserve Bank of New Zealand (2000)).

The solution to avoiding too short a horizon for the inflation target is to set inflation targets for periods two years (or longer) ahead. This automatically implies that the central bank will have multi-year inflation targets. The target for the current calendar year will have been set two years previously, while there will also be a target for the following year. With multi-year targets, the target from one year to the next could vary over time. The inflation target would vary in response to shocks to the economy, especially to supply shocks which might need to be accommodated in order to keep output fluctuations from getting excessive. Also putting a weight on output fluctuations in a central bank's objectives, as is sensible, requires that the approach of the inflation target to the long-run goal needs to be gradual (Svennson, 1997). This also suggests the need for multi-year targets in which the inflation target, even one for two years ahead, may differ from the long-run target if shocks to the economy have driven inflation away from the long-run goal.

Initially, inflation targets in the transition countries studied here were short, being on the order of a year, and the short horizons may have contributed to controllability problem and the frequent target misses. Possibly in response to these problems, the CNB was the first to specify a long-term inflation target for a horizon of five years, and the NBH and the NBP have also specified medium-term inflation targets (Table 2). 


\section{5.b. Who should set the inflation target and decide the speed of disinflation?}

In the 1990s, there has been a significant shift worldwide toward more independent central banks, partly in response to a better understanding of economic costs of political interference with monetary policy and high inflation. While not all central banks have been given complete freedom to set monetary policy targets, most of them gained instrument independence, that is, the freedom to conduct monetary policy without external interference to meet the objective. Among economists, there seems now to be consensus that central banks should have instrument independence, that is, independence to conduct monetary policy so as to meet the inflation target or other monetary policy objective. There seems to be a consensus that central banks should not have goal independence, that is, independence to set inflation targets or other monetary policy objectives (Fischer (1994)).

From the early stages of economic transition, central banks in all three countries have received a significant degree of de jure independence, not only in the conduct of monetary policy (instrument independence) but also in setting the objectives of monetary policy (goal independence).

In the Czech Republic, the independence of the central bank was anchored in the Constitution, which stated that the government may only intervene in the CNB's affairs for reasons clearly outlined in the Act on CNB. The Act on CNB (No. 6/1993 of Collection of Laws) specified that the primary objective of the CNB is to ensure the stability of the Czech national currency (Article 2); that the CNB Board should set monetary policy and the instruments for the implementation of these policies (Article 5). Moreover, the Act explicitly states that in providing for its primary objective, the CNB shall be independent of any instructions given by the Government. The Governor, Vice-Governors and members of the Board are appointed and recalled by the President (Article 6). The Act was subsequently amended in 2002, and the main objective of the CNB was changed to maintain price stability, with the standard qualification that without prejudice to its primary objective, the CNB shall support economic policies of the Government leading to sustainable economic growth. The amended Act also states that "when providing for the primary objective of the CNB and when carrying out their activities, neither the CNB nor the CNB Board shall seek or take instructions from the President of the republics, from Parliament, from the Government, from administrative authorities or from any other body (Article 9). The appointment of the Governor and other CNB officials remains fully the responsibility of the President.

In Hungary, the Act on National Bank of Hungary was passed in October 1991 and reinstated the independence of the NBH. It was amended several times since. The latest version from June 2001 (Act LVIII of 2001) states that the primary objective of the NBH shall be to achieve and maintain price stability (Article 3) and that the NBH shall define and implement monetary policy in the interest of maintaining the stability of the national currency (Article 4). Article 6 states that "within the framework provided for by this Act, the NBH shall independently define its monetary policy and the instruments for implementing such policy." Article 38 stipulates that the Government may not instruct the NBH in relation to its scope of tasks as set forth in the Act. The President of the NBH is appointed for a 
period of six years by the President of the Republic at the proposal of the Prime Minister. The President of the Republics also appoint 3-5 Vice-Presidents and members of the Monetary Council.

The legal position of the National Bank of Poland is similar. The Act on the NBP of August 29, 1997 stipulates that the basic objective of the NBP shall be to maintain price stability, again with the addition that the NBP shall at the same time support the Government economic policies, insofar as this does not constrain pursuit of the basic objective (Article 3). The President of the NBP shall be appointed by the Sejm, at the request of the President of the Republic, for a period of six years. The Vice-Presidents and other members of the NBP Management Board are appointed by the President of the Republic at the request of the President of the NBP. The nine members of the Monetary Policy Council are appointed in equal numbers by the President of the Republics, the Sejm and the Senate (Article 13). The responsibility of the MPC is to draw annual monetary policy guidelines and submit them to the Sejm for information (Article 12). Article 21 stipulates that in discharging its responsibilities, the NBP shall collaborate with the appropriate bodies of the central government in developing and implementing national economic policy and strive to ensure a proper performance of monetary policy guidelines. It should submit monetary policy guidelines to bodies of central government and report on performance of monetary policy.

However, de jure independence does not always imply a de facto independence. While the NBP is not explicitly forbidden by the Act on NBP to seek instructions from the Government and other bodies in pursuing its responsibilities, de facto, it decides alone on inflation targets. On the other hand, the NBH is de jure independent and forbidden to seek instructions, but in practice, the Governor of the NBH seeks Government endorsement for the NBH's monetary policy objectives.

The effort to make central banks legally independent reflected the belief of reformist governments and parliaments that politics should not interfere with the conduct of monetary policy. To a large extent, central bank legislature in these countries was modeled after the German Bundesbank which itself - for historical reasons - enjoyed a high degree of independence. In the early years of transition, no one really questioned the high degree of central bank independence in the transition countries, as governments had to deal with the more urgent tasks of liberalization, privatization etc. However, the high degree of central bank independence eventually became a source of tension.

These tensions appeared first in the Czech Republic. As we have discussed, in the early years of inflation targeting, the CNB has repeatedly undershot its inflation target, while economic growth turned negative. In many countries, this would probably be sufficient to create tensions between central bank and government. In the Czech Republic, these tensions were further aggravated by political developments. To a large extent as a result of poor state of the economy in the aftermath of the currency turbulence of 1997, the main pro-reform party split and new elections were called for mid-1998. In the meantime, a caretaker government was formed and the CNB governor became a caretaker prime minister. When a new government was formed after the election, he returned back to the CNB. Inevitably, this 
has drawn the CNB further into politics, exactly the opposite to what the high degree of de jure independence was supposed to achieve.

The party that lost election in 1998 criticized the CNB and the governor for mishandling monetary policy, contributing to economic decline and thus affecting the outcome of elections. The CNB was considered to be too independent and unwilling to coordinate monetary policy with economic policy of the government. The speed of disinflation was considered as excessive, hurting economic growth. This criticism eventually resulted in legislative effort to curb the CNB's independence. When the CNB and the new government introduced jointly to Parliament an amendment to CNB Act to bring it in line with the EU standards, members of the party that lost the 1998 election submitted their own amendment that aimed at reducing significantly the CNB's independence. They proposed that Parliament would supervise and approve the operational budget, salaries of Board members were to be cut, monetary policy decision were to be consulted with the government, and political partied were to have more say in appointing the governor and Board members.

This proposal was strongly criticized by domestic and foreign financial analysts, by the International Monetary Fund and - most importantly - by the European Union and European Central Bank. Central bank independence is a requirement for both EU and EMU membership, and this argument carried ultimately the largest weight because of the likely accession of the Czech Republic into EU/EMU. In the end, the CNB retained its independence, and with the appointment of new governor in 2000, the relationship with the Government improved as well.

Similar tensions between central bank and government emerged in Poland during 2000 and 2001. As economic growth began to falter while interest rates remained high, the NBP was blamed by some politicians for having its monetary policy excessively tight, and that it contributed to subpar growth performance. Tensions between the government and the NBP accelerated in October 2001, after the new government took office. Contributing to the tensions was the fact that the president of the NBP Leszek Balcerowicz was himself a former politician and main author of the cold-turkey stabilization program that was criticized by the center-left politicians that formed the government after the October 2001 elections.

The prime minister and other members of the cabinet have attacked repeatedly the Monetary Policy Committee (MPC) for keeping interest rates too high. The pressure to reduce the NBP's independence rose and some members of parliament from the two governing parties drew legal proposals to broaden the NBP's objectives to include economic growth and employment, and to increase the number of members of MPC. Even though the government did not formally back these proposals, being well aware that this would complicate the EU/EMU accession, it did not mind using them as a tool to put pressure on the NBP to ease monetary policy. Because accession to EU/EMU is an important objective for Poland, it is not likely that these initiatives will succeed.

The Polish experience also illustrates the peril of central bank effort to use monetary policy as a tool to force the government to pursue a more disciplined fiscal policy. The NBP 
tried to use tight monetary policy to press the government to improve structural fiscal balance, and kept interest rates very high even as inflation was falling below its target and growth came nearly to a halt. But instead of achieving this objective, the NBP has antagonized the government and put its independence under risk.

Even Hungary was not spared tensions between the central bank and the government. Recently, the Government put forward a bill that proposes to set up a Supervisory Committee within the National Bank of Hungary. This Committee would comprise delegates of political parties and two persons appointed by the Minister of Finance. Such a committee already existed in the past but was abolished. The NBH argues that such a step would infringe on NBH's operational independence and would go against the EU requirements on central bank independence. Members of the government have also pressured the NBH to reduce interest rates in order to support growth. They argue that the NBH should not focus to much on inflation.

In Hungary, the reasons for this pressure on the central bank are mainly political and personal. The new NBH president who was appointed in 2001 was a former minister of finance and from this position, he was exercising pressure on his predecessor. However, the previous NBH president is in a close contact with the present prime minister and has used this to create pressure on his successor. More recently, the conflict between the inflation target and exchange rate target has further increased these tensions.

Why do we see these tensions in all three inflation-targeting countries? There are several reasons. First, at the beginning of transition, central banks were given a large degree of both operational and goal independence. In a situation where inflation is still higher than the long-term objective of price stability, this means that central banks are given the freedom to decide on the speed of disinflation. As central bankers tend to be more ambitious with respect to the speed of disinflation than politicians, this creates potential for tensions. These tensions tend to come open once economic growth falters, particularly of this poor growth performance is perceived as contributing to a loss of popularity of the governing party(ies). In our view, this experience suggests the superiority of closer involvement of political authorities in setting monetary policy objectives. Particularly in difficult period of economic transition, goal independence of central banks may complicate rather than facilitate the conduct of monetary policy.

Second, the fact that politicians became central bank governors, or that central bank governors stepped into politics, had the unwanted consequence of drawing central banks more into the political arena. Finally, despite significant progress in economic and political reforms, the rule of law still remains less firmly established even in the most advanced transition economies, making politically motivated attacks on central banks more likely.

The kind of public disputes between the central bank and the government that we have seen in the Czech Republic, Poland and Hungary is not desirable. It undermines the credibility of the inflation targeting framework and could increase the costs of future disinflation. As we have already noted, the decision about the speed of disinflation has 
different impact on different groups in the society, and there is thus a strong case for such decision to be made by a politically responsible body like the government. Clearly, it would serve better the credibility of monetary policy if the speed of disinflation were the result of a joint decision by a central bank and government, though this is not obviously a practice in all inflation-targeting countries. ${ }^{32}$ Such a joint decision would have several advantages. Most important, it would be more credible. When a government decides (perhaps jointly with a central bank) on the speed of disinflation, it is explicitly or implicitly committing itself to policies supporting this disinflation objective. The speed of disinflation (co)decided by government would be seen by markets as a political decision which takes into account possible short-term tradeoffs, and it would reduce the probability that policies supporting the achievement of targeted disinflation would be challenged on grounds that they do not reflect the preferences of the society and that they are unduly costly.

Even in situations where the ultimate responsibility for deciding the speed of disinflation would rest with the government, the central bank could still provide an important input into this decision, by voicing (possibly publicly) its own views about the desirable speed of disinflation. Of course, there is a risk that government would choose too slow a disinflation. However, it is not clear whether this would impose higher costs on the economy than a unilateral decision by a central bank to pursue a more rapid disinflation that would be subsequently challenged by government as being too ambitious. Furthermore, a unilateral decision by the central bank to pursue rapid disinflation is likely to weaken support for the central bank as has occurred in the Czech Republic and Poland. This increases the risk of loss of independence and interference with the ability of the central bank to control inflation in a longer run context.

The question who should set inflation targets has a specific aspect in transition economies that are expected soon to become members of the EMU. One can argue that when the political decision to join the EMU is made, it effectively specified both the disinflation path and the ultimate inflation target. The inflation target is determined by the need to meet the Maastricht criterion concerning maximum permissible inflation, and the speed with which this inflation is to be achieved is determined by the timing of the EMU entry. To the extent that there is a firm political commitment to join the EMU, it becomes to a large extent irrelevant whether the inflation target is set by a central bank or a government. The government does not have much room to be more lenient on inflation than the central bank, because of the possibly large economic and mainly political costs of not meeting the Maastricht criteria.

${ }^{32}$ Such arrangement need not necessary imply a formal subordination of the central bank to government in setting inflation targets. For example, in Australia, the inflation target is set by a central bank alone, and the government subsequently endorses publicly this target. 


\section{5.c. How to respond to deviations of inflation from the target and how much should the floor of an inflation target be emphasized relative to the ceiling?}

The implementation of inflation targeting in the Czech Republic and Poland has brought out an interesting problem that arises in other inflation-targeting economies as well. How to respond to a significant deviation of inflation from the inflation target? If the inflation rate overshoots the ceiling of the target range, then the logic of inflation targeting clearly requires the central bank to bring the inflation rate back into the target range. However, should an inflation-targeting central bank try to lock in a lower than targeted inflation once actual inflation falls below the targeted path if inflation is not yet at the longrun goal? Another way of asking this question is whether a central bank should emphasize the floor of the inflation target as much as the ceiling and thus work as hard to avoid undershoots of the target as overshoots.

As we have noted, the CNB significantly undershot its inflation target in 1998 and 1999, and less so in 2000. Similarly, at the end of 2001, inflation in Poland fell well below the NBP end-2001 target. What should central banks do in such situations? Should they be upset at the undershoot and indicate that this was a serious mistake. Alternatively, would it be appropriate for them to lock in the unexpectedly rapid disinflation of previous two years, and focus its monetary policy on maintaining from then on price stability?

A case could be made for acting opportunistically and using faster than expected disinflation to lock in this windfall benefit of lower inflation (Haldane (1998)). This is what Poland has tried to do, by adjusting its original end-1999 inflation target after actual inflation early in 1999 began to fall faster than projected. It would seem that when inflation has been reduced to less than the central bank target, but remains still above the level of inflation corresponding to price stability, it would make no sense to let inflation go up again, only to be forced to reduce it again later. Disinflation, even at a moderate pace, could be costly, and if a country can avoid the need to disinflate in the future, this should spare the economy some loss of output. Whether past faster than planned disinflation was a result of luck or mistakenly tight monetary policy may seem not to matter, bygones are bygones, past costs, if any, have been incurred, and let's just avoid any future costs of disinflation. ${ }^{33}$

In practice, central banks have treated the floors of inflation target range in different ways (Clifton (1999)). Some treat them as seriously as upper sides of a band, and eased monetary policy to bring inflation back up inside the band (e.g., New Zealand in 1991), while others preferred to consolidate the unexpected rapid disinflation (Israel in 1998,)

The recent experience of Poland has shown the risks of trying to lock into lower than originally targeted inflation. There are several problems with opportunistic disinflation and

${ }^{33}$ Of course, such an argument could be made only if inflation does not fall below the longterm inflation target corresponding to price stability. 
for treating the bottom of the band leniently. First, there is a possibility that opportunistic disinflation will not find much sympathy with politicians. Particularly if the faster than originally intended disinflation coincides with a significant weakening of economic activity, there will be calls for a relaxation of monetary policy, even if this should mean a return to somewhat higher inflation. The NBP has exacerbated this problem because its inflation target is now stated to be "less than 4\%," suggesting that they are not particularly disturbed by undershooting the inflation target. This may have contributed substantially to the poor relations between the NBP and the government and a decrease in public support for the NBP. The CNB was well aware of the danger from its undershoots of the inflation target, and did not even suggest that it could lock in the lower than targeted inflation.

Second, if rapid disinflation is a result of temporary external shocks like large declines in the price of commodities, it would be a mistake to assume that monetary policy could lock in such disinflation forever without large future costs. Once these shocks are over, prices of commodities usually do not stay low, but rise again, as global demand recovers. Monetary policy that would try to prevent accelerated pace of disinflation at times of declining commodity prices or other positive supply shocks would be probably too expansive. In the same vein, monetary policy would risk being too restrictive if it would try to avoid any acceleration of inflation as positive supply shocks are reversed. ${ }^{34}$ Like many other inflation-targeting central banks, the CNB has explicitly recognized that monetary policy should not attempt to offset temporary supply shocks that knock disinflation from its projected path.

Third, an opportunistic approach to disinflation could undermine the credibility of an inflation targeting framework. By setting medium-term inflation targets, central banks attempt to establish a predictable environment that would allow economic agents to plan for the future. Even though there could and will be deviations from the target, credible inflation targeting would lead the agents to expect that a central bank would do its best to return actual inflation to the targeted path. Attempts at opportunistic disinflation could increase the uncertainty, because it would make monetary policy less predictable. For example, economic agents could expect that central banks would adjust an inflation target upward in case of a negative shock as well.

However, a situation may arise where the path of disinflation has been set incorrectly. For example, competitive pressures in the economy, due to liberalization, privatization and a more open trade would produce a faster disinflation for a given monetary policy stance that originally expected. These favorable supply shocks would be likely to cause inflation to undershoot without leading to a decline in output. In this case, maintaining the original disinflation target would require an overly expansionary monetary policy, and it would seem to be more appropriate to accept in such case a faster than originally intended disinflation.

${ }^{34}$ If a positive price shock would be permanent, perhaps as a result of a sudden increase in productivity, it would be appropriate to accommodate the effect of such shocks on inflation. 
This would also likely be politically feasible because the undershoot of the inflation target would not be accompanied by output losses.

\section{5.c. Inflation targets and the exchange rate}

In the recent literature on inflation targeting, particularly on inflation targeting in emerging market countries, increased attention has been paid to the open-economy aspect of inflation targeting (Mishkin, 2000, Mishkin and Savastano, 2001, and Eichengreen, 2001). It has been recognized that the large degree of openness of some emerging market economies, in combination with specific characteristics of their financial systems, create additional challenges for the implementation of inflation targeting. Exchange rate movements affect directly domestic inflation, both as a result of external shocks and as a result of monetary policy measures. The open economy aspect of inflation targeting plays a prominent role in inflation-targeting transition economies as well.

In the initial stage of transition, all three inflation-targeting countries analyzed in this paper used a fixed exchange rate as a nominal anchor to import price stability and bring domestic inflation quickly down. The currency peg-based stabilization was quite effective, because it allowed them to bring down inflation relatively quickly. The initial monetary overhang was eliminated by a one-time increase in price level, rather than by a sustained growth in prices, and thus its elimination did not become embedded in inflation expectations. However, first Poland, then Czech Republic and finally Hungary abandoned the currency peg and moved to more flexible exchange rate arrangements. This has fundamentally changed the operation of monetary policy and the operation of the monetary transmission mechanism.

The importance of the exchange rate channel of monetary policy depends directly on the degree of openness of the economy to trade flows, and on the degree of integration into international capital markets. The Czech Republic and Hungary are very open economies with respect to trade flows. The share of exports plus imports in GDP exceeds 100 percent in Hungary and the Czech Republic. Poland is a more closed economy: the share of exports plus imports reaches "only" about 50 percent. Therefore, exchange rate movements in the Czech Republic and Hungary will have a more important effect on domestic prices and inflation, and thus for inflation targeting. At the same time, all three countries are very open to international capital flows, because in preparation for the EU membership, they have largely completed capital account liberalization.

There are several reasons why exchange rate movements are important for inflation targeting in transition countries (Svensson (2000)). First, exchange rate movements provide an additional transmission channel of monetary policy. While in a closed economy, aggregate demand and expectation channels dominate, in open economy, the exchange rate channel may be the most important one, particularly in the short-run. The exchange rate transmission channel operates both directly and indirectly. Changes in nominal exchange rate affect 
directly the domestic prices of imported final goods, and thus the targeted CPI index. ${ }^{35}$ Indirectly, the exchange-rate channel operates by affecting domestic demand. Changes in real exchange rate affect domestic and foreign demand for domestic goods, and thus enhance the standard aggregate-demand channel. Second, the exchange rate is one channel through which foreign disturbances could be transmitted into the domestic economy. Third, transition countries also have a particular concern with their exchange rates because they went to become part of the European Union and the euro zone. Thus they must eventually fix their exchange rates to the euro as part of their planned entry into the Economic and Monetary Union and so naturally care more about what exchange rate they will convert their currency into the euro upon accession.

Finally, it should be noted that emerging market countries and transition economies are usually more vulnerable to large exchange rate movements. The reason is the underdeveloped capital market in domestic currency and the need to borrow in dollars or other foreign currency, except for a very short-term borrowing. This results in open foreign exchange positions of banks and/or corporations, and thus increased vulnerability of their balance sheets to large exchange rate movements. While large appreciation can make domestic producers uncompetitive (both in foreign and domestic markets), large depreciation could cause large damage to firms or banks with large open foreign exchange position and precipitate a financial crisis of the type described in Mishkin $(1996,1999)$

While it is generally recognized that in such open economies like the Czech Republic and Hungary, the exchange rate represents both an important channel of monetary transmission and an important channel of transmission of external disturbances, it is less obvious what are the implications for the treatment of exchange rate in the regime of inflation targeting. We can distinguish two approaches to exchange rate: an active and passive approach. In an active approach, the central bank cares about the exchange rate over and above its effects on inflation and actively tries to influence the level of the exchange rate. In a passive approach, a central bank cares about the exchange rate only to the extent it affects aggregate demand and the inflation rate and it does not try to directly manipulate the exchange rate and only reacts to changes in exchange rate that would threaten its inflation target. $^{36}$

35 The CPI index includes prices of both domestic and imported goods. As such, it represents a combined measure of domestic inflation and imported inflation. Domestic inflation is also affected by changes in prices of imported goods indirectly. Changing the price of imported input used for production of domestic goods would affect costs, and - depending on the extent of the pass-through - domestic prices.

${ }^{36}$ Again, we can distinguish a more or less active use of this passive approach, depending on the time horizon during which the central bank would try to meet inflation target by responding to exogenous exchange rate changes. 
As we have noted, particularly the Czech Republic and Hungary are very open economies, and exchange rate will therefore have important effect on inflation and other variables. Poland is less open, and exchange rate movements seem to play a less important role in monetary policy deliberations. It seems that the NBH is pursuing this active approach, as judged from its statements on the role of exchange rate in affecting inflation outcomes. As Orlowski (2000) argues, in Hungary, the central bank has focused its monetary policy on exchange rate stability, and for this reason, changes in exchange rates have a strong effect on inflation. Such a strong effect was not observed in the Czech Republic and Poland. This may explain the relatively larger emphasis put by the NBH on the exchange-rate channel of monetary policy.

The problem is that too much reliance on the exchange-rate channel of monetary transmission carries the risk that a central bank would focus excessively on a short-term horizon. In open economies, the exchange-rate channel is not only important, but operates very fast, because changes in exchange rate affect directly domestic prices of imported final goods, and with longer but still potentially quite short lag prices of domestic goods containing imported inputs. This rapid transmission may induce the inflation-targeting central bank into too much of a focus on a short-term horizon, and to try to keep actual inflation in line with inflation target by orchestrating exchange rate changes. However, excessive use of the exchange rate channel could have undesirable consequences. It could cause a problem of instrument instability, result in excessive variability of real exchange rate, and thus in an increased degree of uncertainty in the economy and higher variability of output. ${ }^{37}$ In addition, it runs the risk of transforming the exchange rate into a nominal anchor that takes precedence over the inflation target. For example, as documented in Bernanke et al (1999), Israel's intermediate target of an exchange rate around a crawling peg did slow the Bank of Israel's effort to win support for disinflation and lowering of the inflation targets in the early years of its inflation targeting regime. In addition, an active focus on the exchange rate may induce the wrong policy response when a country is faced with real shocks such as a terms-of-trade shock. Two graphic examples of these problems are illustrated by the experience in New Zealand and Chile in the late 1990s.

The short horizon for the inflation target in New Zealand led the Reserve Bank to focus on the exchange rate as an indicator of the monetary policy stance because of the direct impact of exchange rate movements on inflation. By early 1997, the Reserve Bank institutionalized this focus by adopting as its primary indicator of monetary policy a Monetary Conditions Index (MCI) similar to that developed by the Bank of Canada. The idea behind the MCI, which is a weighted average of the exchange rate and a short-term interest rate, is that both interest rates and exchange rates on average have offsetting impacts on inflation. When the exchange rate falls, this usually leads to higher inflation in the future, and so interest rates need to rise to offset the upward pressure on inflation. However, the offsetting effects of interest rates and exchange

${ }^{37}$ This risk seems to be well recognized by the NBH. See National Bank of Hungary (2001), pp. $35-36$ 
rates on inflation depend on the nature of the shocks to the exchange rates. If the exchange rate depreciation comes from portfolio considerations, then it does lead to higher inflation and needs to be offset by an interest rate rise. However, if the reason for the exchange rate depreciation is a real shock such as a negative terms-of-trade shock which decreases the demand for a country's exports, then the situation is entirely different. The negative terms-of-trade shock reduces aggregate demand and is thus likely to be deflationary. The correct interest rate response is then a decline in interest rates, not a rise as the MCI suggests.

With the negative terms-of-trade shock in 1997, the adoption of the MCI in 1997 led to exactly the wrong monetary policy response to East Asian crisis. With depreciation setting in after the crisis began in July 1997 after the devaluation of the Thai baht, the MCI began a sharp decline, indicating that the Reserve Bank needed to raise interest rates, which it did by over 200 basis points. The result was very tight monetary policy, with the overnight cash rate exceeding $9 \%$ by June of 1998 . Because the depreciation was due to a substantial, negative terms-of-trade shock which decreased aggregate demand, the tightening of monetary policy, not surprisingly, lead to a severe recession and an undershoot of the inflation target range with actual deflation occurring in 1999. ${ }^{38}$ The Reserve Bank of New Zealand did eventually realize its mistake and reversed course, sharply lowering interest rates beginning in July 1998 after the economy had entered a recession, but by then it was too late. It also recognized the problems with using an MCI as an indicator of monetary policy and abandoned it in 1999. Now the Reserve Bank operates monetary policy in a more conventional way, using the overnight cash rate as its policy instrument, with far less emphasis on the exchange rate in its monetary policy decisions.

Chile's inflation targeting regime also included a focus on limiting exchange rate fluctuations by having an exchange rate band with a crawling peg which was (loosely) tied to lagged domestic inflation. This focus on the exchange rate induced a serious policy mistake in 1998 because the central bank was afraid it might lose credibility in the face of the financial turmoil if it allowed the exchange rate to depreciate after what had taken place in financial markets after the East Asian crisis and the Russian meltdown, Thus instead of easing monetary policy in the face of the negative terms-of-trade shock, the central bank raised interest rates sharply and even narrowed its exchange rate band. In hindsight, these decisions were a mistake: the inflation target was undershot and the economy entered a recession for the first time in the 1990 s. $^{39}$ With this outcome, the central bank came under strong criticism for the first time since

\footnotetext{
${ }^{38}$ The terms-of-trade shock, however, was not the only negative shock the New Zealand economy faced during that period. Its farm sector experienced a severe drought which also hurt the economy. Thus, a mistake in monetary policy was not the only source of the recession. Bad luck played a role too. See Drew and Orr (1999) and Brash (2000).

${ }^{39}$ Because, given its location in Latin America, Chile's central bank did have to worry more about loss of credibility and also because Chile encountered a sudden stop of capital inflows at the time, the ability of the Chilean central bank to pursue countercyclical policy was more limited than for the Australian central bank. However, although lowering interest rates in
} 
it had adopted its inflation targeting regime in 1990, weakening support for the independence of the central bank and its inflation targeting regime. During 1999, the central bank did reverse course, easing monetary policy by lowering interest rates and allowing the peso to decline.

The contrast of the experience of New Zealand and Chile during this period with that of Australia, another small open economy with an inflation targeting regime is striking. Prior to adoption of their inflation targeting regime in 1994, the Reserve Bank of Australia had adopted a policy of allowing the exchange rate to fluctuate without interference, particularly if the source of the exchange rate change was a real shock, like a terms-of-trade shock. Thus when faced with the devaluation in Thailand in July 1997, the Reserve Bank recognized that it would face a substantial negative terms-of-trade shock because of the large component of its foreign trade conducted with the Asian region and that it should not fight the depreciation of the Australian dollar that would inevitably result (McFarlane (1999) and Stevens (1999)). Thus in contrast to New Zealand, it immediately lowered the overnight cash rate by 50 basis points to $5 \%$ and kept it near at this level until the end of 1998, when it was lowered again by another 25 basis points.

Indeed, the adoption of the inflation targeting regime probably helped the Reserve Bank of Australia to be even more aggressive in its easing in response to the East Asian crisis and helps explain why its response was so rapid. The Reserve Bank was able to make clear that easing was exactly what inflation targeting called for in order to prevent an undershooting of the target, so that the easing was unlikely to have an adverse effect on inflation expectations. The outcome of the Reserve Bank's policy actions was extremely favorable. In contrast to New Zealand and Chile, real output growth remained strong throughout this period. Furthermore, there were no negative consequences for inflation despite the substantial depreciation of the Australian dollar against the U.S. dollar by close to $20 \%$ : inflation remained under control, actually falling during this period to end up slightly under the target range of 2 to $3 \%$.

While it would not be desirable if a central bank tried to actively manipulate the exchange rate, this does not imply that it should not respond to an exchange rate shock. However, whether it should respond or not, and how it should respond, depends on the nature of the shock. As illustrated above, the response to a real shock to the exchange rate such as a change in the terms-of-trade should be entirely different from the reaction to a portfolio shock.

The relevant question concerning the transition economies is, what types of shock are they likely to face in the period ahead of the EU/EMU membership? And how vulnerable are they to large exchange rate movements? How much they should be concerned about exchange rate movements for other reasons than the risk that inflation target will not be met?

1998 may not have been as attractive an option, the sharp rise in the policy interest rate in 1998 was clearly a policy mistake. 
Besides the standard shocks that all open emerging market economies could face, transition economies could face specific external shock related to the EU accession: specifically, the convergence play. The convergence play refers to capital inflows to accession countries stimulated by the expected behavior of interest rates and exchange rate ahead of the EMU accession. Countries that have joined the EMU in the past have experienced a sizeable decline in the currency risk premium of their debt, that is, the premium to compensate the debt holders for the risk that their currency would loose value. The decline in currency risk premium resulted in lower interest rates on their debt instruments in local currency, and thus higher price of these instruments. Increased prices allowed holders of these instruments to realize capital gains. Therefore, investors could reasonably expect that transition countries that have joined the EU will soon join the EMU as well, and from the past experience, they could expect a reduction in interest rates on debt instruments issued by these countries that would allow them to reap capital gains. In other words, these investors have incentive to play on the convergence of interest rates to EMU level and invest in fixed-income instruments issued by accession countries. The resulting increase in capital inflows and currency appreciation could be viewed as a pure portfolio shock that would require interest rate reduction. But reducing interest rates could conflict with the inflation target, because it could stimulate domestic demand too much and result in faster increase in domestic prices. On the other hand, if monetary policy does not respond, the large capital inflow could lead to the standard problems of excessive currency appreciation, balance of payments problems, and reversal of capital flow resulting in currency depreciation and higher inflation.

Complicating the problem even more is the exposure of accession countries to a second shock - in this case a real shock. It has been well documented that as transition economies catch up with the more developed EU countries, they experience rapid productivity growth, which produces real exchange rate appreciation, either by means of nominal appreciation or by means of a higher inflation. In this case, the appreciation of the domestic currency should be seen as an equilibrium phenomenon, which is sustainable and does not require a monetary policy response. In sum, in the period ahead of the EU/EMU membership, accession countries could be exposed to two simultaneous external shocks that would tend to produce exchange rate appreciation, but which would call for a different policy response. In practice, it could be difficult to disentangle what part of the currency appreciation is the result of the portfolio shock and what part results from the real shock. Balance of payments data on the size and composition of capital flows, and data on productivity growth should provide some indication of relative importance of these two types of shocks

The recent experience of the Czech Republic illustrates yet another problem: currency appreciation caused by a large inflow of foreign direct investment (FDI) as a result of sale of state-owned enterprises to foreign owners. One can argue that currency appreciation resulting from the inflow of FDI is the typical real shock that does not call for a monetary policy response: the currency appreciates, but FDI inflow results in more investment, better management etc., and ultimately in higher productivity, which validated the appreciation of the currency. This argument has two problems. First, while currency appreciation will 
happen always when there is a sale of domestic assets to foreigners for foreign currency, it is less sure that the increase in productivity validating the currency appreciation will follow. For example, a large part of recent sales consisted of utilities where the potential for increasing the competitiveness in export markets is limited. Second, there is a time discrepancy between the timing of the currency appreciation (immediately) and the productivity increase (later). And third, expectation of currency appreciation as a result of sales to foreigners of state-owned assets could itself induce investors to take positions in the domestic currency, in order to benefit from the expected appreciation once the privatization payment materializes. This would produce a currency appreciation even before the privatization-related capital inflow materializes.

All this complicates significantly the task of inflation-targeting central bank. To the extent that currency appreciation reflects an equilibrium phenomenon, appreciation of the real equilibrium exchange rate, there would be little reason for concern. Such appreciation would not threaten economic growth and external equilibrium, and if inflation is still above the long-term target, it should help the central bank to bring inflation down. But how much should a central bank worry if this real appreciation is too fast and too large? It could result in a widening current account deficit and subsequent large exchange rate depreciation, with negative effects on inflation. And it could cause problems in corporate sector, because adjustment to a fast and large currency appreciation could be more difficult. The standard prescription for a central bank dealing with large capital inflows and currency appreciation is sterilized intervention: buy foreign currency in foreign exchange market and neutralize monetary effects of this intervention by selling bonds. Eventually, this intervention could be complemented by interest rate cuts, to reduce the incentive for capital inflows.

But this prescription may be of little help in the circumstances like those in the Czech Republic in the 2001-2002. Large capital inflows are mainly in the form of FDI, and not attracted by a large interest rate differential. Reducing interest rates is not going to slow down FDI inflows. These are interest rate-insensitive. Sterilized intervention would be possible, but this policy has its own problems. In order to be effective, it would have to be of a very large amount (in the order of several billions of dollars) and it may not even be effective at all. Sterilizing such intervention would be quite costly for the central bank. ${ }^{40}$

For these reasons, the CNB has pursued a pragmatic strategy of gradual interest rate reduction, combined with occasional foreign exchange market intervention of limited magnitude. This intervention has been subsequently sterilized. The CNB recognizes that at present, currency appreciation reflects mainly the effect of the FDI inflow, as that it is therefore a real shock that the monetary policy has no business of neutralizing. However, the speed of the appreciation could be occasionally too fast, and at that point, the CNB feels that it could slow down the pace of appreciation by intervening, so that the corporate sector has more time to adjust to the trend appreciation. In late 2002, capital inflows related to the

${ }^{40}$ Of course, with falling interest rate differential, the costs of sterilization decline as well. 
convergence play (the portfolio shock) were not a serious issue for the Czech Republic, partly because the convergence play and the compression of yield spreads had already taken place. $^{41}$ Otherwise, the situation would have been even more complicated.

Another reason for not having benign neglect of the exchange rate is emphasized in Mishkin (2000) and Mishkin and Savastano (2001). For the reasons discussed earlier, transition countries with a lot of foreign-denominated debt may not be able to afford large depreciations of their currencies which can destroy balance sheets and trigger a financial crisis. Central banks in these countries my thus have to smooth "excessive" exchange rate fluctuations, but not attempt to keep the exchange rate from reaching its market determined level over longer horizons. The stated rationale for exchange rate smoothing would be similar to that for interest-rate smoothing, which is practiced by most central banks, even those engaged in inflation targeting: the policy is not aimed at resisting market-determined movements in the exchange rate, but at mitigating potentially destabilizing effects of abrupt changes in exchange rates.

The challenges facing the central bank are somewhat different in Hungary. As was noted, Hungary still maintains an exchange rate band \pm 15 percent. In the literature on inflation targeting, it is often emphasized that the absence of a second nominal anchor is one of the prerequisite of the successful inflation targeting. Pursuing two nominal objectives could result in a situation where one objective will need to be given preference over the second objective, but without a clear guidance how such conflict would be resolved, this could make monetary policy less transparent. ${ }^{42}$ The question arises, to what extent might the existence of the \pm 15 percent exchange rate band in Hungary be considered as a second nominal anchor whose attainment could eventually conflict with the inflation target? The answer has turned out to be "a lot".

In mid-February, the exchange rate of the forint hovered some 12-13 percent above the parity, approaching quickly the upper part of the band. Partly as a result of uncertainty related to parliamentary election, the currency weakened somewhat during the Spring and Summer, but it began to appreciate again later in 2002. In January 2003, it approached the upper end of the band, and speculation about the revaluation of the parity resulted in a sharp acceleration of capital inflow that forced the NBH to respond by cutting interest rates by 2 percentage points and intervening heavily in the foreign exchange market. The NBH is reported to have bought more than 5 billion euros, increasing international reserves by 50

${ }^{41}$ In fact, at the end of 2002, spreads on domestic currency sovereign bonds compared to the benchmark German bonds were negative for all maturities. See Ceska Sporitelna/Erste bank (2002). Of course, the question is whether such dramatic compression of yield spreads is sustainable.

${ }^{42}$ On the experience with inflation targeting in the presence of nominal exchange rate band in Israel, see Leidermann (2000). 
percent and base money by 70 percent. ${ }^{43}$ Even though the NBH began subsequently to sterilize this huge injection of liquidity, market participants now assume that maintaining the exchange rate band will have a priority over the inflation target and expect inflation in 2003 to exceed the NBH inflation target.by 5 percentage points.. ${ }^{44}$

This conflict between the inflation target and exchange rate target need not be a unique problem for Hungary. Other accession countries could face this problem once they become members of the EU and once they decide to join the ERM2 mechanism that requires them to limit exchange rate fluctuations exactly in the same way as Hungary does already today, that is, to peg the currency against the euro and allow maximum \pm 15 percent fluctuation around the established parity. Therefore, we now turn to the issue of monetary policy implementation in the period after the EU accession and before the EMU accession.

\section{Monetary policy within the ERM2 System}

The participation in the ERM2 mechanism and subsequently in the EMU is obligatory for all new EU members (no opt-out clause available). Albeit, the new EU members do not have to join the ERM2 mechanism immediately after the EU entry. Therefore, after joining the EU, the new members will have to decide on how quickly to join the ERM2 mechanism and thus the EMU, and whether the ERM2 membership would require a modification of the inflation targeting framework.

How would monetary policy in the accession countries operate under the ERM2 regime, and what would be the main nominal anchor of the economy? Formally, the monetary policy framework after joining the ERM2 mechanism will be similar to the monetary policy framework in Hungary today, where the \pm 15 percent fluctuation band is already in place. But there will be also important differences. First, the actual EMU entry will be approaching, which could have important implications for capital flows (convergence play) and fiscal policy implementation (need to meet fiscal criteria). Second, breaching the target band (its lower side) would have different consequences for Hungary today and for accession countries operating within the ERM2 regime. Third, unlike Hungary's monetary policy today, monetary policy and exchange rate of an accession country within the ERM2 regime will be of common interest to all EMU members, and the European Central Bank (ECB) could intervene to help the accession country to keep the exchange rate within the band.

The ERM2 fluctuation band will allow rather large exchange rate movements, too large to provide a sufficiently firm nominal anchor. For this reason, the inflation target will

${ }^{43}$ See J.P. Morgan (2003).

${ }^{44}$ Analysts have interpreted this as an evidence that the NBH is determined to maintain the currency band even at the cost of temporary higher inflation. See IMF (2002). 
likely need to continue to play the role of nominal anchor as it did in Spain before its entry into EMU (see Bernanke et al., 1999). Successful operation of inflation targeting after the ERM2 entry should be facilitated by the fact that the process of disinflation is likely to be largely completed. Low inflation could reduce, though not fully eliminate, the probability that the inflation target would conflict with the commitment to maintain the currency within the ERM2. Still, the possibility of a conflict between the inflation target and the ERM2 exchange rate band cannot be fully excluded. But it is important to be clear about the nature of this risk and how it could be mitigated.

Within a ERM2 framework, two situations could arise where monetary and other policies may need to be constraint by the fact that the exchange rate is approaching the lower or upper side of the band. One possibility is that the exchange rate would approach the upper (appreciated) band, as is now happening in Hungary. In order to prevent breaching the permitted fluctuation band, interest rates may need to be reduced to moderate the pressure on the currency. But lower interest rates could interfere with the inflation target, because they could stimulate domestic demand more than the central bank considers prudent, and could produce higher inflationary pressures. However, a strongly appreciating currency would simultaneously also act as a mechanism to dampen inflationary pressures, so it is not at all obvious that this conflict with inflation target would actually become serious. ${ }^{45}$ If reducing interest rates would not help, and pressures on the currency to appreciate would persist, another option would be to revalue the central parity. ${ }^{46}$ This would reduce the burden of monetary policy and at the same time introduce a one-time deflationary shock.

A different conflict between inflation target and exchange rate band would arise if there is a downward pressure on the currency and if the exchange rate threatens to break through the lower (more depreciated) end of the band. Breaching the ERM2 lower target band would force the country to start again the ERM2 two-year test, so it could be potentially costly. Central banks could react to such a situation by tightening monetary policy and raising interest rates. But this response certainly should not conflict necessarily with the inflation target. On the contrary, it should be in line with the inflation-targeting policy if the reason for downward pressure was too relaxed a policy. And tighter monetary policy would also help to mitigate inflationary pressures that may arise from currency depreciation. Tighter monetary policy would also be appropriate in the case when the currency depreciates as a result of a negative portfolio shock. Higher interest rates should help arrest capital outflow, by making domestic currency assets more attractive. But the situation could be more

\footnotetext{
${ }^{45}$ The direct effect of the appreciated exchange rate on inflation will be felt sooner than the indirect effect of reduced interest rates on aggregate demand and demand-induced acceleration of inflation.

${ }^{46}$ For countries in the ERM2 framework, the ECB would also be expected to help a national central bank to sustain the currency inside the fluctuation band, of course, to the extent that this does not interfere with the ECB's price stability objective.
} 
complicated when the currency depreciates as a result of negative real shock which at the same time reduced aggregate demand for domestic output (domestic or foreign demand). Maintaining the currency within the fluctuation band could require a tighter policy stance than what would be required if monetary policy were guided only by the inflation target. As a result, actual inflation would become lower than the inflation target, and monetary policy would further weaken demand and economic activity that was already affected adversely by the negative real shock. Under the normal circumstances, this would not be desirable. But temporary lower economic activity may be a price worth paying in a situation where the alternative would be to violate the Maastricht criterion of two years of successful operation within the ERM2 system, thus delaying the EMU entry.

To some extent, fiscal policy could be used to reconcile eventual conflict between inflation target and ERM2 band. First, maintaining a fiscal policy stance that would clearly indicate authorities' determination to meet Maastricht criteria of public debt and fiscal deficit would reduce the risk of downward pressure on the currency as a result of a negative portfolio shock. It would also allow the maintenance of lower interest rates than if fiscal policy were more expansionary, and thus reduce short-term capital inflows. Second, a changing fiscal policy stance could be used as a defense against large exchange rate movements threatening to breach the ERM2 band. Fiscal policy could be tightened even more than what is required by Maastricht criteria in case of downward pressure on the currency that would threaten to break the lower side of the band, or - to the extent that meeting Maastricht criteria is not threatened - it could be relaxed in case of upward pressure on the currency. But in this case, using interest rate policy would be clearly preferable as a first line of defense.

The risk of conflict between the inflation target and exchange rate target will depend importantly on market expectations of conversion rate of the national currency into the euro. If market participants expect that the current market rate will be also the conversion rate, there will be less risk of such conflict as the behavior of market participants should actually limit the fluctuation of the actual exchange rate. However, widespread market expectation that future conversion rate will differ significantly from the current exchange rate could result in large and volatile capital flows and swings in actual exchange rate that could severely complicate the simultaneous achievement of inflation target (sufficiently low inflation to meet the Maastricht criteria) and exchange rate target (keeping the currency within the fluctuation band).

How should inflation targets be set after the countries will have joined the EU and eventually the ERM2 mechanism? The obvious answer is to set the inflation target in such way that it would converge to inflation rate estimated to be consistent with the Maastricht criterion. Table 6 shows the annual inflation rate in three current EMU members with lowest inflation rate in the period 1995-2001. If we add to the average of inflation in three euro area best performers and the 1.5 percentage point margin allowed by the Maastricht Treaty, we receive the maximum permissible inflation in the accession countries that would be applied if they were to join the EMU in that particular year. 
Table 6. Lowest inflation rates in EMU countries, 1995-2000

\begin{tabular}{|l|l|l|l|l|l|l|l|}
\hline & 1995 & 1996 & 1997 & 1998 & 1999 & 2000 & 2001 \\
\hline Country A & 0.8 & 0.6 & 1.2 & 0.8 & 0.5 & 1.7 & 1.6 \\
\hline Country B & 1.5 & 1.3 & 1.3 & 0.9 & 0.6 & 1.9 & 2.5 \\
\hline Country C & 1.7 & 1.4 & 1.4 & 0.9 & 0.6 & 2.3 & 2.5 \\
\hline $\begin{array}{l}\text { Average } \\
\text { inflation }\end{array}$ & 1.3 & 1.1 & 1.3 & 0.9 & 0.6 & 2.0 & 2.2 \\
\hline $\begin{array}{l}\text { Maastrict } \\
\text { Criterion } \\
\text { inflation 1/ }\end{array}$ & 2.8 & 2.6 & 2.8 & 2.4 & 2.1 & 3.5 & 3.7 \\
\hline
\end{tabular}

$1 /$ Average inflation in three countries plus 1.5 percentage points. Average inflation rounded up.

Source: United Nations (2002).

If we take the period 1995-2001 as a benchmark, the inflation rate that the accession countries would have to reach in order to meet the Maastricht criterion was in the range 2.13.7 percent. In 1998 and 1999, inflation in the euro area countries was particularly low, and it would thus seem that reaching the Maastricht objective would have been particularly challenging for accession countries at that time. However, we should note that to some extent, exceptionally low inflation in the euro area was a part of global tendency of falling inflation, which affected the transition economies as well. To the extent that inflation in the euro area and in the transition economies waiting to join the EMU moves jointly in response to common external shocks like falling commodity prices and weak global economic activity accompanied by large excess production capacity and weak pricing power of producers, lower permissible inflation does not make it necessary more difficult (does not require a tighter monetary policy) to qualify for the EMU.

We can also see that the range of maximum permissible inflation 2.1-3.7 percent is broadly in line with the long-term inflation targets in the Czech Republic (2-4 percent), Hungary (around 2 percent) and Poland (less than 4 percent).

\section{Conclusion}

In this paper, we have discussed the experience with inflation targeting in the three transition economies - the Czech Republic, Hungary and Poland. We have examined the circumstances leading to the switch from exchange rate pegs to inflation targeting and the modalities of inflation targeting in each of these countries. The short history of inflation targeting in these three countries does not yet allow us to draw any definitive conclusions about the success or failure of this regime. However, we conclude that inflation targeting in transition economies could be implemented reasonably successfully. While the examined countries have missed inflation targets often by a large margin, they nevertheless progressed 
well with disinflation. Still, increased uncertainty prevailing in transition economies makes it particularly difficult to predict inflation sufficiently well ahead, as required by a forwardlooking nature of inflation-targeting approach. In view of that, and given the possibility that transition countries will be more frequently hit by shocks that could divert inflation from the targeted path, misses of inflation targets are more likely than in the more advanced economies.

This does not imply that monetary policy targeting other nominal variables like monetary aggregates would make the task of controlling inflation easier. Even though inflation targeting in transition economies is more difficult than in advanced economies, it could still bring significant benefits. It should be clear, though, that too much focus on hitting inflation targets at any price at all times could produce a significant instability of monetary policy instruments, damaging economic performance. The focus of inflation-targeting central banks should be on the medium-term horizon to ensure that disinflation remains on track and that inflation converges to level deemed consistent with price stability. Alongside this trajectory, there will inevitably be misses, possibly sizeable. Thus, the onus is on central banks' ability to communicate to the public clearly what are the limits and possibilities of inflation targeting in transition economies, and if it happens, to explain credibly and openly why inflation targets were missed.

A key lesson from the experience of the inflation targeting transition countries is that economic performance will improve and support for the central bank will be higher if central banks emphasize avoiding undershoots of the inflation target as much as avoiding overshoots. Undershoots of the inflation targets have resulted in serious economic downturns that has eroded support for the central bank in both the Czech Republic and Poland. Also economic performance will be enhanced if inflation targeting central banks in transition countries do not engage in active manipulation of the exchange rate. This seems to be less of an issue in the Czech Republic and Poland, but is still a live issue in Hungary.

A difficult problem for inflation targeting in transition countries is the often stormy relationship between the central bank and the government. This can be alleviated by having a direct government involvement in the setting of the inflation target and with a more active role of the central bank in communicating with both the government and the public. In addition having technocrats appointed as the head of a central bank rather than politicians may help in depersonalizing the conduct of monetary policy and increase support for the independence of the central bank.

We have also addressed the future perspective of monetary policy in the transition economies. We concluded that even after the EU accession, inflation targeting can remain the main pillar of monetary strategy in the three examined accession countries during the time before they will join the EMU. Inflation targets would be guided toward meeting the Maastricht criteria for inflation, which would require maintenance of inflation at the level defined in long-term inflation objectives. 
In addition, an important advantage of the inflation targeting regimes in transition countries is that the central banks in the countries practicing inflation targeting have been learning how to set monetary policy instruments to hit their inflation goals. Since these central banks will have a role in setting monetary policy instruments at the ECB when they enter EMU, the monetary policy experience that they have acquired by operating an inflation targeting regime, will help them play a more active and positive role in deliberations at the ECB. 


\section{References}

Akerlof, George et al. (1996), “The Macroeconomics of Low Inflation.” Brookings Papers on Economic Activity, 1, pp. 1-76,

Ball, Lawrenece (1994), "What Determines the Sacrifice Ratio?" In N. Gregory Mankiw (ed.), Monetary Policy. University of Chicago Press, Chicago.

Begg, David (1998), "Pegging Out: Lessons from the Czech Exchange Rate Crisis," Journal of Comparative Economics 26, 669-690.

Bernanke, B. S., Laubach, T., Mishkin, F.S. and A. S. Posen 1999. Inflation Targeting. Lessons from the International Experience. Princeton, New Jersey. Princeton University Press.

Brash, Donald T. (2000). "Inflation Targeting in New Zealand, 1988-2000," Speech to the Trans- Tasman Business Cycle, Melbourne, February 9.

Calvo, Guillermo and Frederic S. Mishkin (2003). "The Mirage of Exchange Rate Regimes for Emerging Market Countries," Journal of Economic Perspectives, forthcoming.

Capek, Aleš (1999), "Udrñet inflaci pod kontrolou bude stále obtíñn־iší’ ("Keeping Inflation Under the Control Will Be Ever More Difficult”), Hospodálské noviny, October 22, p. 9.

Ceska Sporitelna/Erste Bank (2002), Macroeconomic and Fixed Income Weekly Report, December 16.

Clifton, Eric V. (1999), "Inflation Targeting: What is the Meaning of the Bottom of the Band?” IMF Policy Discussion Paper, 99/8.

Clinton, Kevin (2000), "Strategic Choices for Inflation Targeting in the Czech Republic." In Warren Coats, ed., Inflation Targeting in Transition Economies: The Case of the Czech Republic. Czech National Bank and the International Monetary Fund.

Czech National Bank (1997). Monthly Bulletin, 1997/5.

Czech National Bank (1999), Inflation Report, January.

Debelle, Guy (1997), "Inflation Targeting in Practice," IMF Working Papers 97/35

Drew, Aaron and Adrian Orr, 1999. "The Reserve Bank's Role in the Recent Business Cycle: Actions and Evolution," Reserve Bank of New Zealand Bulletin, 62, No. 1. 
Eichengreen, Barry (1999), "Solving the Currency Conundrum." Paper prepared for the Council of Foreign Relations Study Group on Economic and Financial Development (http://elsa.berkeley.edu/users/eichengr/htm.)

Eichengreen, Barry (2001), "Can Emerging Markets Float? Should They Inflation Target?" Mimeo, see http://elsa.berkeley.edu/users/eichengr/POLICY.HTM

Estrella, Arturo and Frederic S. Mishkin (1997), "Is There a Role for Monetary Aggregates in the Conduct of Monetary Policy," Journal of Monetary Economics 40:2 (October) pp. 279-304.

European Bank for Reconstruction and Development (2002), Transition Report 2002.

Fischer, Stanley (1994), "Modern Central Banking," in Forrest Capie, Charles A. Goodhart, Stanley Fischer and Norbert Schnadts, Eds., The Future of Central Banking: The Tercentenary Symposium of the Bank of England, pp. 262-308. Cambridge, Cambridge University Press, 1994.

Groshen, Erica L. and Schweitzer, Mark E. (1996). "The Effects of Inflation on Wage Adjustments in Firm-Level Data: Grease or Sand?" Federal Reserve Bank of New York Staff Reports, No. 9.

Groshen, Erica L. and Schweitzer, Mark E. (1999). "Identifying Inflation's Grease and Sand Effects in the Labor Market," in Martin Feldstein, ed., The Costs and Benefits of Price Stability (University of Chicago Press, Chicago): 273-308.

Haldane, Andrew (1998), "Pursuing Price Stability: Evidence from the United Kingdom and Other Inflation-Targeters", in Czech National Bank, Workshop on Inflation Targeting, Prague.

International Monetary Fund (1999), World Economic Outlook, October 1999.

International Monetary Fund (2001), "Monetary and Exchange Rate Regimes in Central European Economies on the Road to EU Accession and Monetary Union. Unpublished.

International Monetary Fund (2002), Global Market Monitor, December 17.

Kysilka, Pavel (1998), "Nezdravý rÇst dlouho nevydrñ." ("Unhealthy Growth Will Not Be Sustainable") Ekonom, 4, 10-12.

Leidermann, Leonardo (2000), "Inflation Targeting Under a Crawling Band: Lessons from Israel," in Mario Blejer et al. (eds), "Inflation Targeting in Practice: Strategic and Operational Issues and Application to Emerging Market Economies." International Monetary Fund, Washington, D.C. 
Mishkin, F.S. (1996) "Understanding Financial Crises: A Developing Country Perspective," in Michael Bruno and Boris Pleskovic, eds., Annual World Bank Conference on Development Economics 1996 (World Bank: Washington D.C.): 29-62.

Mishkin, F.S. (1999), "Lessons from the Asian Crisis," Journal of International Money and Finance, 18, 4 (August): 709-723.

Mishkin, F.S. (2000), "Inflation Targeting in Emerging Market Countries," American Economic Review (May), Vol. 90, \#2: 105-109.

Mishkin, F.S. (2001), "Issues in Inflation Targeting," in Price Stability and the Long-Run Target for Monetary Policy, (Bank of Canada: Ottawa, Canada, 2001): 203-222.

Mishkin, F.S. and M.A. Savastano (2001), "Monetary Policy Strategies for Latin America." Journal of Development Economics, 66, No. 2, 415-444.

Mishkin, F.S. and Klaus Schmidt-Hebel (2002), "One Decade of Inflation Targeting in the World: What Do We Know and What Do We Need to Know?" ) in Norman Loayza and Raimundo Soto, eds., Inflation Targeting: Design, Performance, Challenges (Central Bank of Chile: Santiago 2002): 117-219.

Morgan, J.P. (2003), Emerging Europe, Middle East \& Africa Weekly, January 31.

National Bank of Hungary (2001), Quarterly Report on Inflation, August.

National Bank of Poland (1998), Medium-Term Strategy of Monetary Policy.

National Bank of Poland (2001), Inflation Report 2000, appendix 2.

Orlowski, Lucjan T. (2000), "Direct Inflation Targeting in Central Europe." Post-Soviet Geography and Economics, 41, No. 2, pp. 134-154.

Schaechter, Andrea et al. (2000), "Adopting Inflation Targeting: Practical Issues for Emerging Market Countries.” IMF Occasional Paper 202, Washington, D.C.

Siklos, Pierre L. and István Ábel (2001), “Is Hungary Ready for Inflation Targeting?” Mimeo

Stock, James H. and Mark W. Watson, (1999), "Business Cycle Fluctuations in U.S. Macroeconomic Time Series", in J.B. Taylor and M. Woodford, eds., Handbook of Macroeconomics. Amsterdam, Elsevier, pp. 3-64.

Summers, Larry (1991), "Panel Discussion: Price Stability; How Should Long-Term Monetary Policy Be Determined?" Journal of Money, Credit and Banking, Vol. 23, August, part II, pp. 625-631. 
Svensson, Lars E.O. (1997), "Inflation Forecast Targeting:Implementing and Monitoring Inflation Targets," European Economic Review, Vol. 41, pp. 1111-1146.

Svensson, Lars E.O. (2000), “Open-Economy Inflation Targeting.” Journal of International Economics, 50, pp. 155-183.

Škreb, Marko (1998), “A Note on Inflation.” In: Carlo Cotarelli a György Szapari, eds., Moderate Inflation. International Monetary Fund and National Bank of Hungary, pp. 179184.

United Nations Economic Survey of Europe, 2002, No. 1. 
Figure 1. Czech Republic. Annual Inflation and Inflation Targets

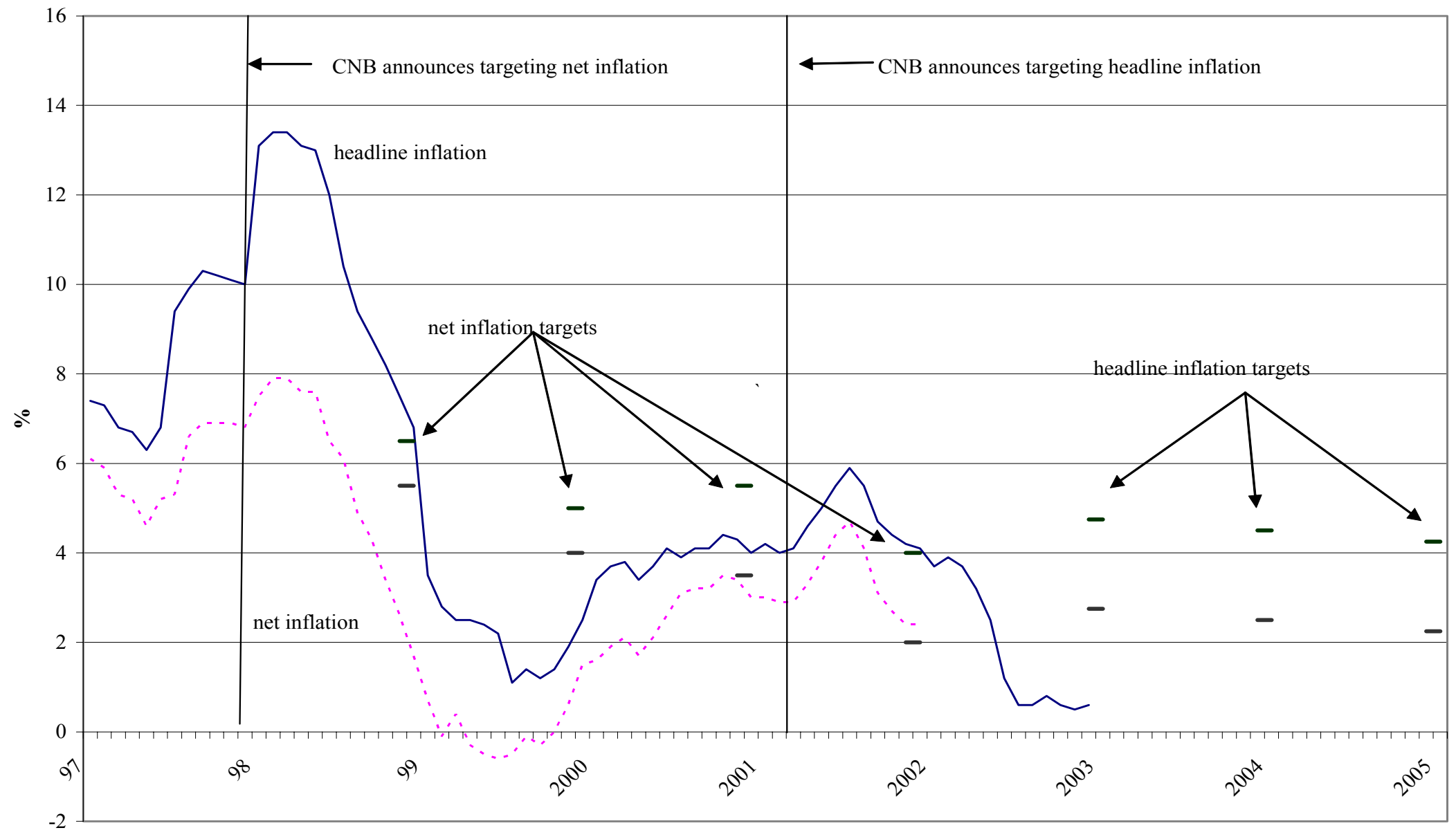


Figure 2. Poland: Actual Inflation and Inflation Target

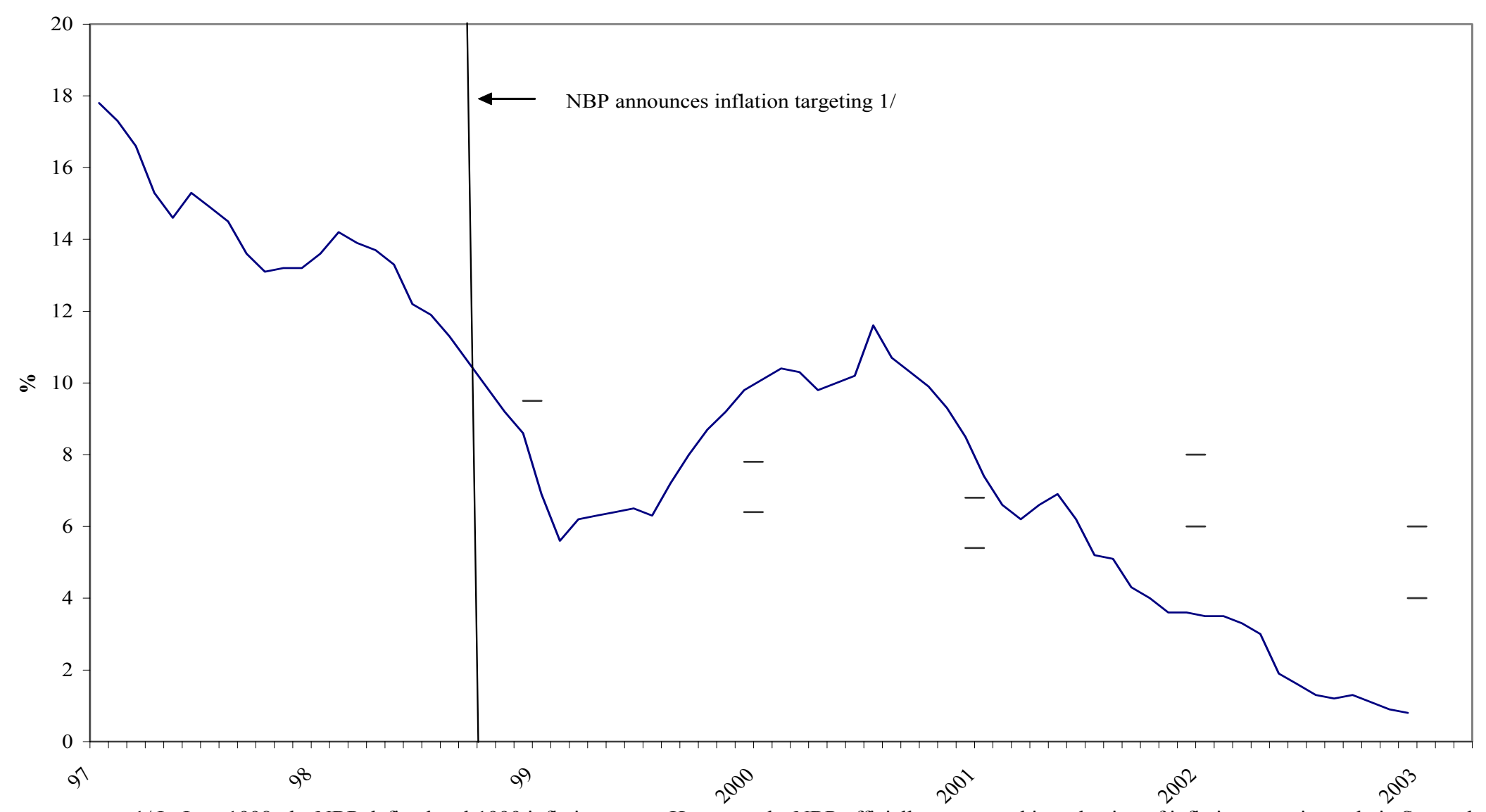

1/ In June 1998, the NBP defined end-1999 inflation target. However, the NBP officially annoucned introduction of inflation targeting only in September

\section{Year over year}

Source: Central Statistical Office Poland 
Figure 3. Hungary: Actual Inflation and Inflation Targets

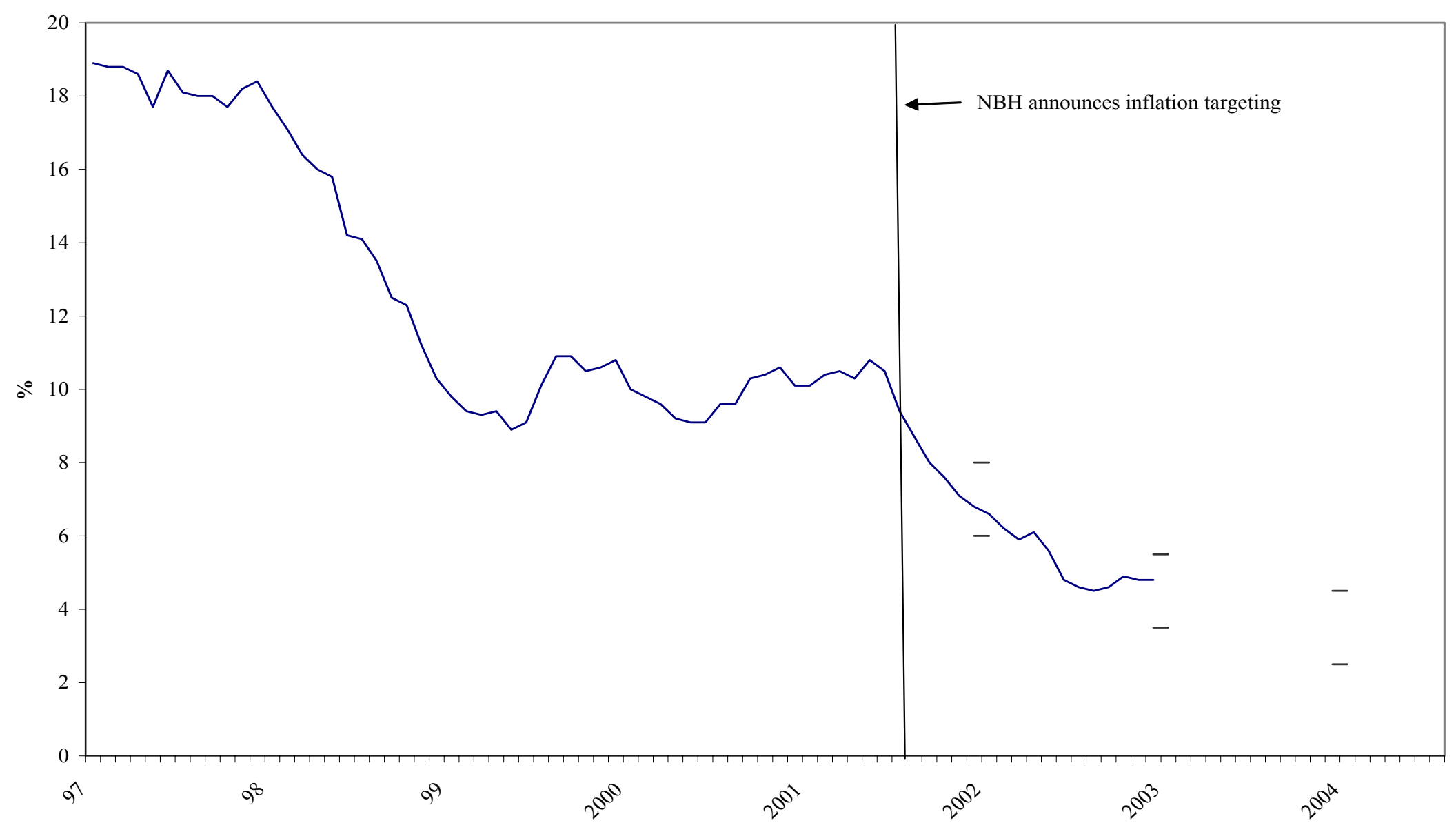

Year over year

Source: Hungarian Central Statistical Office 
Figure 4. Inflation in Czech Republic, Poland and the Non-inflation Targeting Floaters

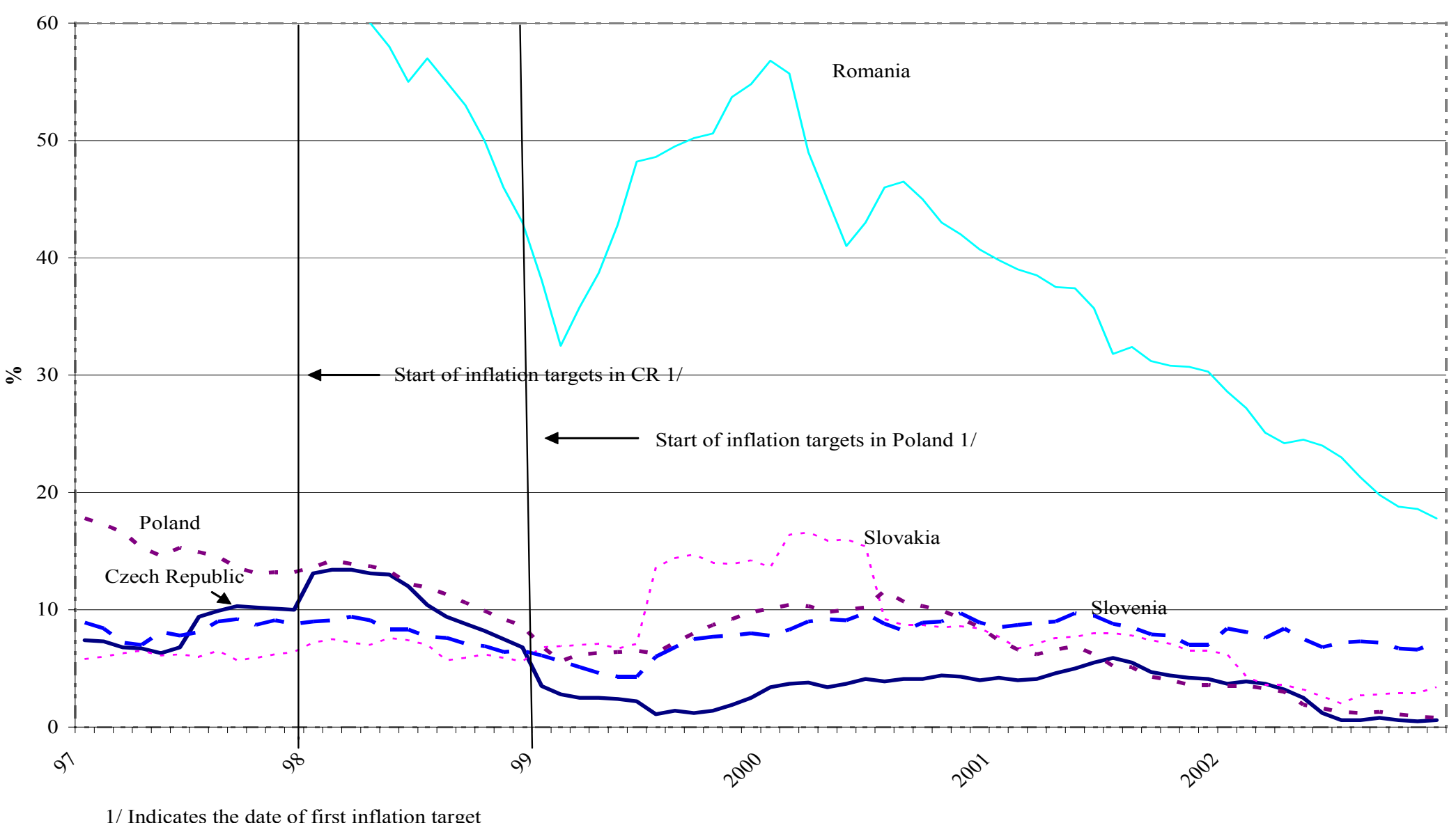

Year over year

Source: Czech Statistical Office, Central Statistical Office Poland, Statistical Office of the Republic of Slovenia., Statistical office of the Slovak Republic, National Statistical Office of Romania. 
Figure 5. Inflation in the Czech Republic, Poland and Countries With Peg

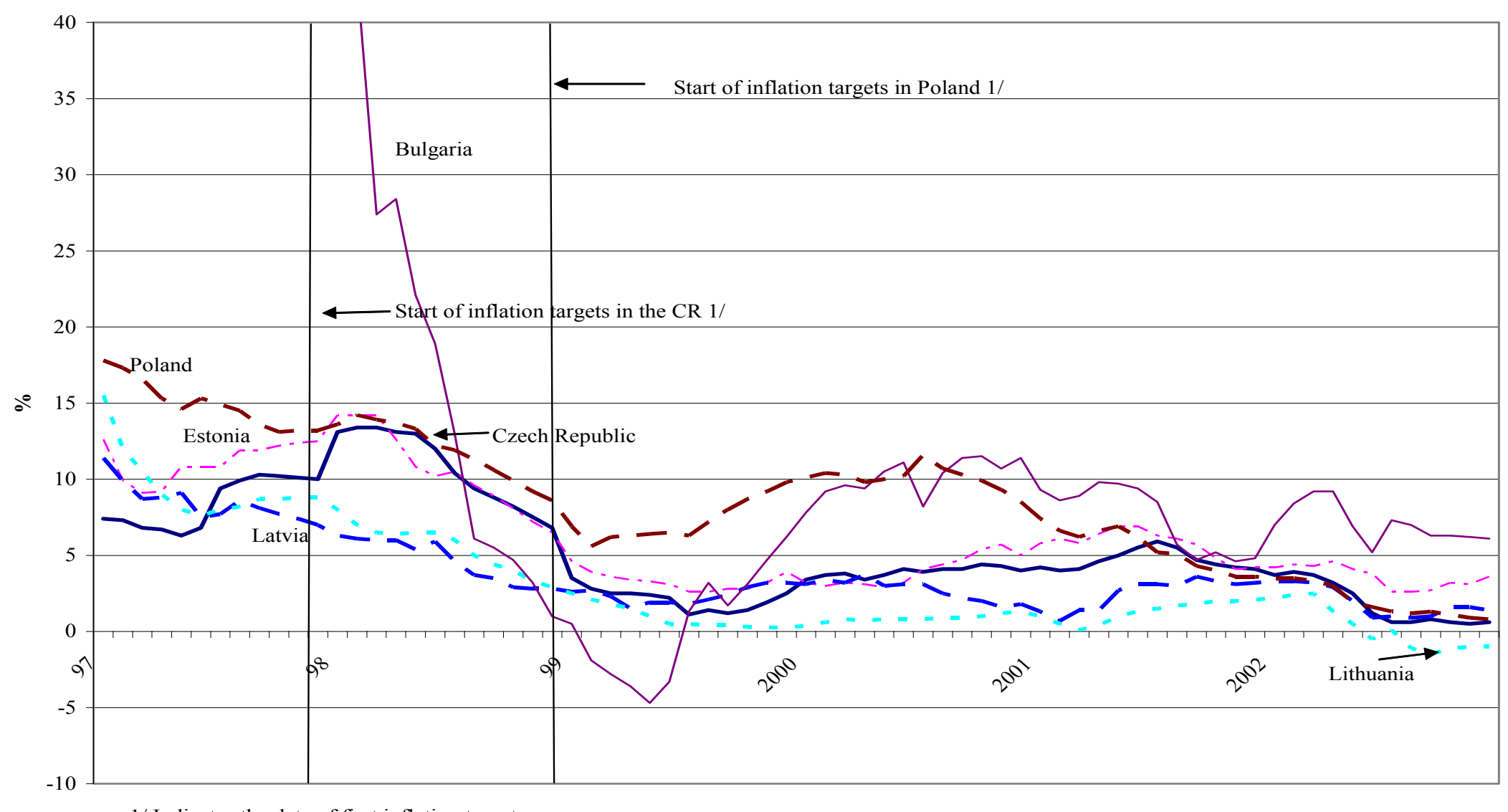

$1 /$ Indicates the date of first inflation target

Year over year

Source: Czech Statistical Office, Central Statistical Office Poland, NBP, National Statistical Office of Bulgaria, Statistical office of Estonia, Statistical Office of the Republic of Slovenia., Statistical office of the Slovak Republic. Statistics Lithuania, Central Statistical Bureau Latvia. 
Figure 6. Transition Economies: Real GDP $(1997=100)$

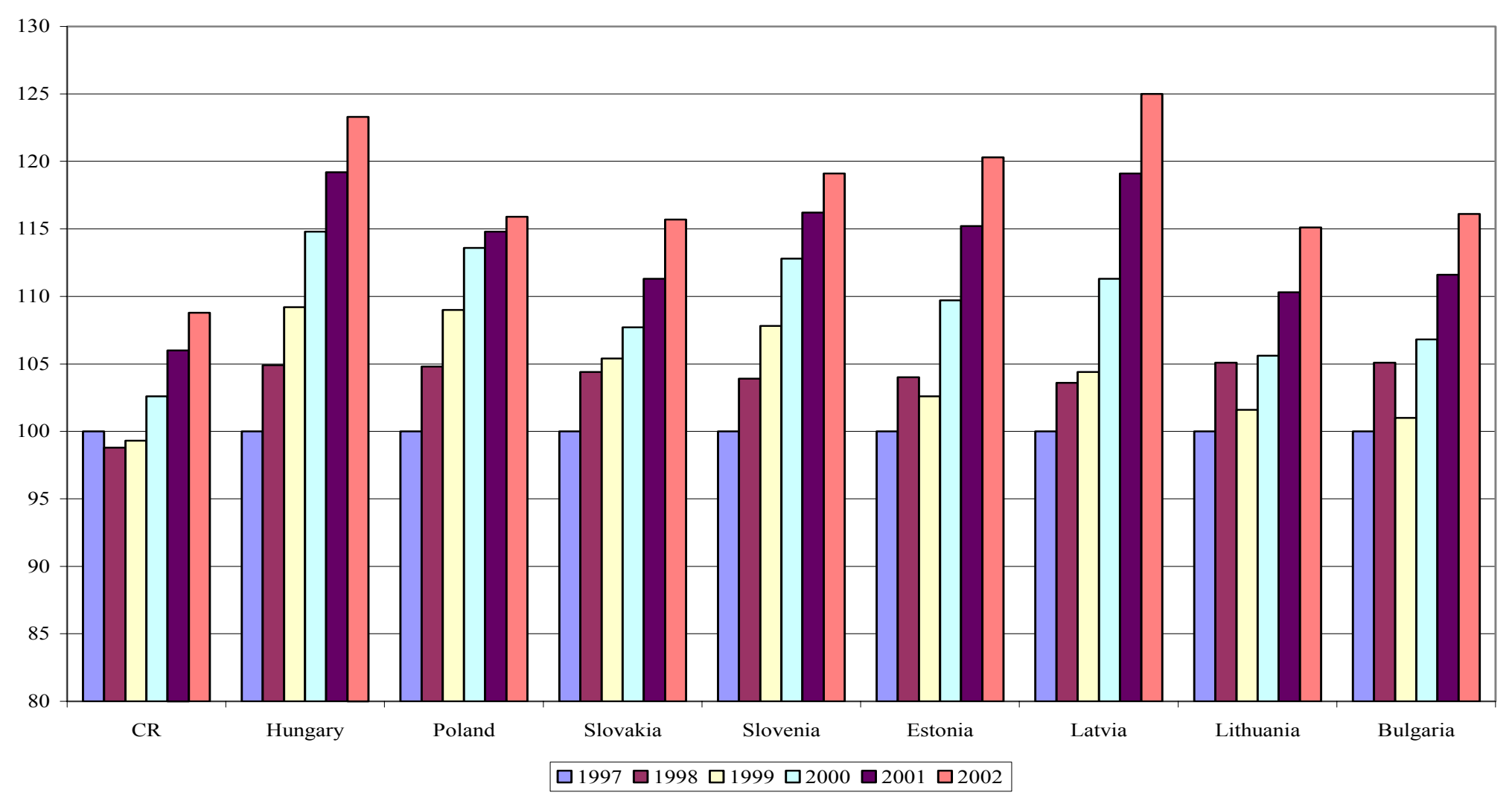

Source: Czech Statistical Office, Central Statistical Office Poland, National Statistical Office of Bulgaria, Statistical office of Estonia, Statistical Office of the Republic of Slovenia., Statistical office of the Slovak Republic, Statistics Lithuania, Central Statistical Bureau Latvia, 